\title{
Features, boundaries and connecting mechanisms of the Mauritanian Province exemplified by oceanic fish larvae
}

\author{
H.-Ch. John* \& C. Zelck \\ Zoologisches Institut und Museum; Martin-Luther-King-Platz 3, 20146 Hamburg, \\ Germany
}

\begin{abstract}
The Mauritanian Province, which comprises the area from the NW-African shelf to about $20^{\circ} \mathrm{W}$ and from Cape Timiris to Cape Verde, is redefined on the basis of fish larvae distribution patterns, direct and indirect current measurements, CTD-O2 hydrography and SST-remote sensing. Its northern and western boundaries coincide with the permanent, although not stationary, Cape-Verde-Frontal-Zone separating North- and South-Atlantic-Central-Water masses. Its southern boundary is characterized by tropical temperatures throughout the year. The oceanic Mauritanian Province is a myctophid dominated system that lacks genuine endemic species. Many deep-mesopelagic species of Myctophidae as well as other families are absent or rare in its centre, whilst some northern oceanic Myctophidae acquire a pseudoceanic character and prosper. On the other hand, tropical species of both oceanic and neritic origin co-occur alongside such cold-temperate Myctophidae. Distribution patterns of fish larvae were partly directly dependent on currents intruding into the province and partly indirectly on the impact of the circulation system on the local hydrography. Local hydrography could affect the survival capability of either larvae or adults. While an oxygen deficit southeast of the frontal zone is a limiting factor for subsurface-epipelagic and mesopelagic species, southwestward Ekman-drift and the related temperature deficit hampers the intrusion or survival of tropical fish larvae with neustonic or shallow vertical distribution. Southern, deep living or eurybathic species with lower temperature preferences are transported into or even beyond the province by northward currents. A transport model describing the input/output mechanisms of the province and defining its limiting features is presented and discussed in respect to recent literature.
\end{abstract}

\section{INTRODUCTION}

The "Mauritanian Upwelling Region" was originally defined by Backus et al. (1977) on the basis of the mesopelagic fish family Myctophidae (Fig. 1). The offshore boundaries were at that time depicted on the basis of temperature data alone. The status as a region was based on the occurrence of two supposedly endemic species (Symbolophorus kreffti and Lampadena pontifex). Hulley (1981) found that the distribution of these two species was not restricted to that region. Even though myctophid biomass values were generally comparable, at least a portion of this area can be regarded as a discrete province, since the species composition, diversity and the rank order of individual species differ strikingly from that of adjacent areas.

\footnotetext{
- Member of the Taxonomy Group at the Biologische Anstalt Helgoland

(O) Biologische Anstalt Helgoland, Hamburg
} 


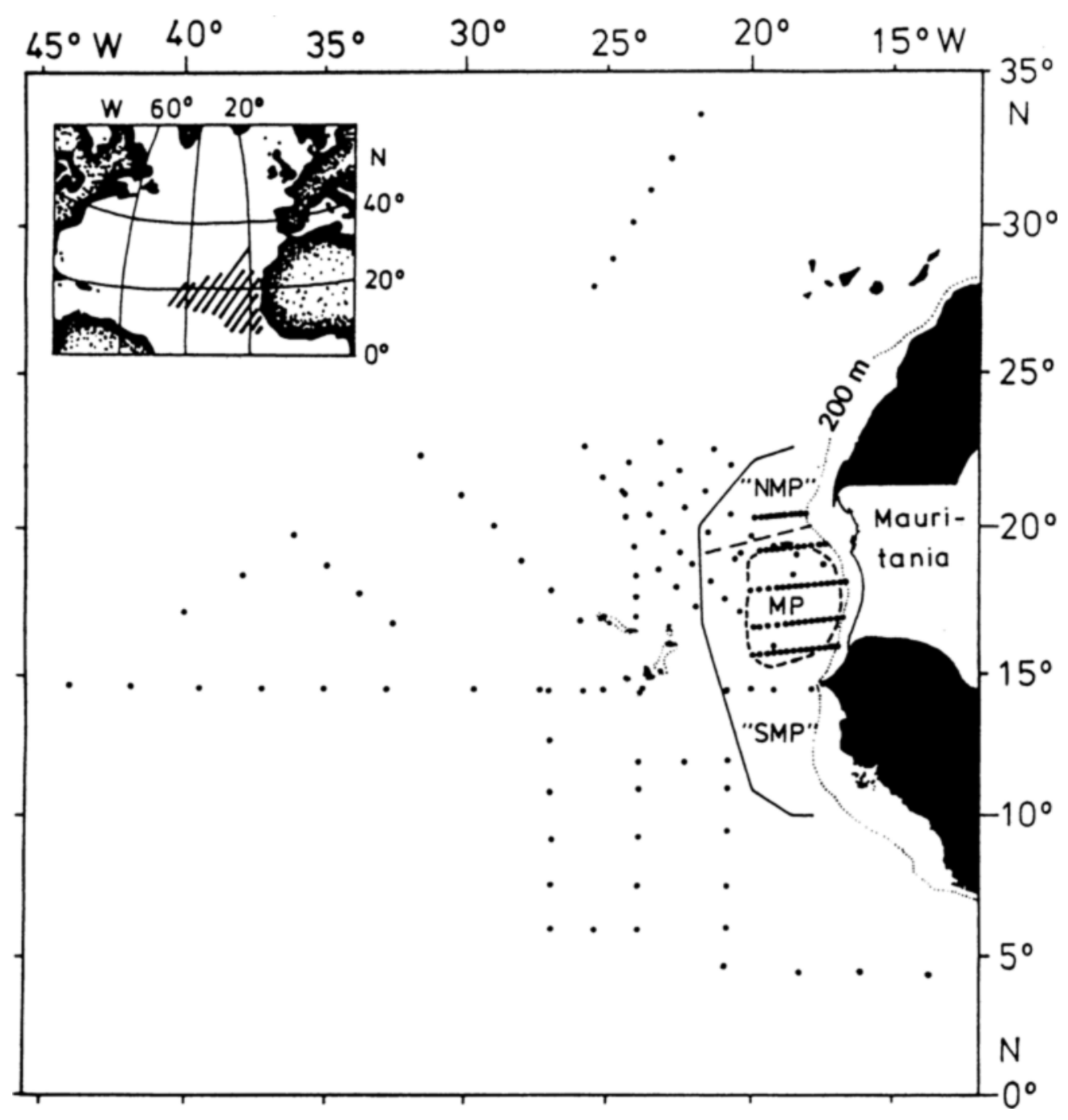

Fig. 1. The station grid analysed in relation to the boundaries of the "Mauritanian Upwelling Region" as originally defined by Backus et al. (1977). The inset shows the location of the station grid (diagonal hatching) in the North Atlantic Ocean. The Mauritanian Region had been originally divided into a northern and southern Mauritanian Province ("NMP" and "SMP", separated by the dashed line). The area in the centre of the Mauritanian Bight and depicted as MP is the Mauritanian Province as defined in this study

Also based on Myctophidae, the area has been classified as "unique in the North Atlantic in that its species assemblage comprises species with northern, subtropical, and tropical distribution patterns" (Badcock, 1981). This holds widely true also for coastal fishes (Maurin, 1968), and was generally explained with the upwelling-related zonal temperature deficit (Briggs, 1974). The zonal temperature deficit along the NE-Atlantic boundary was described by Wooster et al. (1976). Additionally, off Mauritania among euphausids 
an endemic of the Southeast Atlantic upwelling area was reported to be first ranking (Weigmann-Haass, 1976).

Several myctophids of the subpolar-temperate and temperate-oceanic assemblages acquire a pseudoceanic capacity along the West African slope towards tropical latitudes, and can be top ranking there (Badcock, 1981). Furthermore, Badcock related peak abundances of other shelf-break mesopelagic fish taxa to the along-slope undercurrent system.

John (1986) reviewed the data from NW-African quantitative fish larvae surveys. He pointed out that some elsewhere ubiquitous and abundant larvae of oceanic species were almost absent off Mauritania. These "anomalies" could not be related to the zonal temperature deficit alone, but other physical and perhaps biological features must contribute also to the unusual species composition in the Mauritanian upwelling area.

Numerous studies on fish larvae in the Mauritanian coastal upwelling regime have been published (John, 1986 and literature therein). The data presented below are the first biological data to describe the western and southern boundaries of the Mauritanian Province. They will be used to exemplify some characteristics of the Mauritanian Province and to examine the interactions of adult and larval ecology with the hydrographic regime.

\section{MATERIAL AND METHODS}

Generally the data presented below are a synopsis of 3 cruises by the German RV "Meteor" (Met). These are Met 64, January-February 1983 (maps cut off at the shelf edge for reasons given below); Met 6, November-December 1987; and Met 9, January-February 1989. For cruise reports see Siedler et al. (1983), Müller et al. (1988) and Zenk et al. (1989). The individual station grids, shown in Figure 2, yielded a total of some 40000 fish larvae. Additionally, previously published data for some neustonic species from two

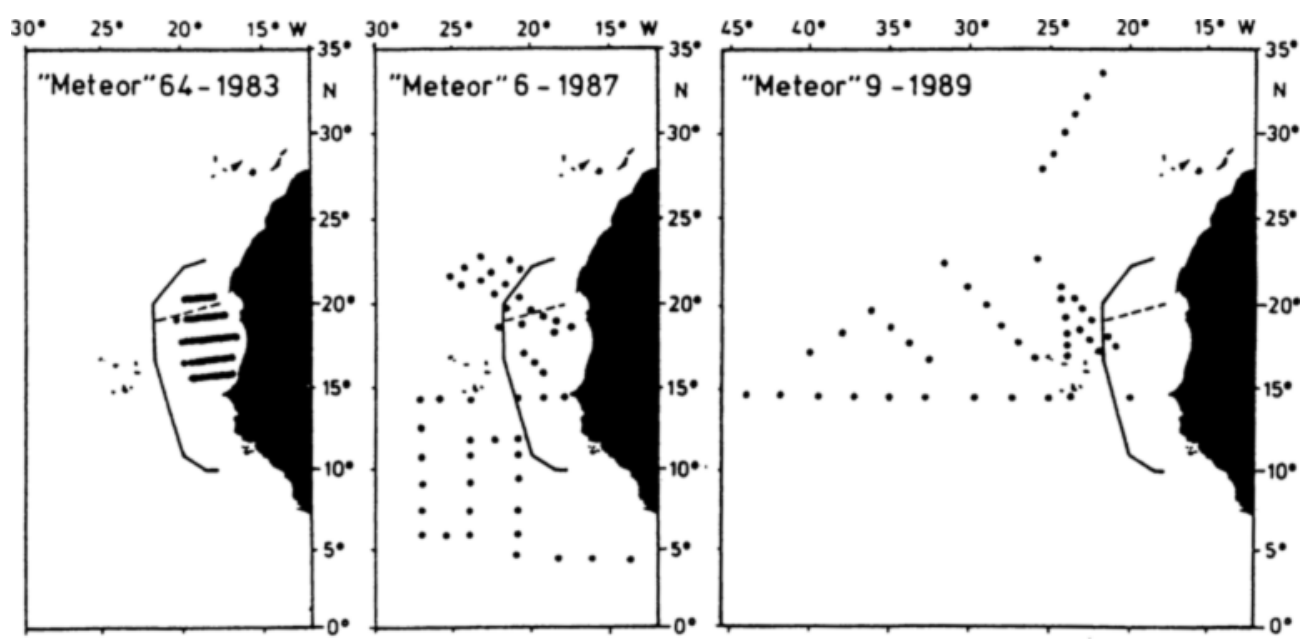

Fig. 2. The individual station grids of the three surveys in relation to the boundaries of the "Mauritanian Upwelling Region" 
open-ocean neuston surveys were pooled with the above mentioned data (see Andres \& John, 1984; John, 1976/77).

For Met 6 and 9 in-situ hydrographical data are available, while for Met 64 such information is restricted to two surveys one month later (references given below).

Species compositions and abundances were obtained using neuston-net (NEU) surface tows, and multiple-opening-closing-net (MCN) hauls from the depth range 200-0 m. The NEU sampled uniformly on average $600 \mathrm{~m}^{2}$ per cast. The MCN was towed obliquely during Met 6 and 9 , with an average sampled area of $3.1 \mathrm{~m}^{2}(\mathrm{~s}=0.5 ; \mathrm{n}=94)$. During Met 64 vertical tows with up to 4 replicates per station were made down to a depth of $1150 \mathrm{~m}$, but reduced to an identical $200 \mathrm{~m}$ interval (average sampled area $0.33 \mathrm{~m}^{2}$; $\mathrm{s}=0.02 ; \mathrm{n}=84$ ). Met 64 and (to facilitate comparisons) 7 coastal stations of Met 6 had finer vertical resolutions than open ocean stations. For larval taxa with defined vertical distributions, respective depth profiles were included into the distribution maps.

While the overall sampling effort per area should be representative for each cruise due to the much denser station spacing during Met 64, the differences in the MCN-effort per station (order 9: 1 for oblique versus vertical tows) limit the possibility of quantitative statistical comparisons among cruises (Whittaker, 1975).

Therefore a K-means cluster analysis (Statistica, 1994) was run on the basis of the relative abundances of species (or higher taxa, see below), in order to group stations by their faunistic similarities. Since identification to species level in some genera like e.g. Cyclothone and Vinciguerria was feasible only for the less abundant postflexion larvae, regroupings to higher taxonomic levels were necessary for the cluster analysis. However, such semiquantitative, taxonomically more detailed data occasionally were used to draw more meaningful specific distribution maps. The statistical analysis included the shelf stations of Met 64 .

At the coastal stations abundances of pseudoceanic and neritic fish larvae were one to two orders of magnitude higher than in the open ocean. This, plus the high horizontal resolution near the coast, did not allow for a combined presentation with comparable scales. As the original results from the coastal zone have been published in detail (see, for example, Bás et al., 1985; Hermes, 1987; John et al., 1991 for overviews, original data, or literature), coastal patterns either had to be omitted or, where relevant, generalized.

\section{RESULTS}

\section{General patterns}

The material comprised 170 identified fish taxa. The most abundant oceanic species and genera contributed a maximum of $7.1 \%$ and $9.3 \%$, respectively, to the total catch of individual surveys, while the rank orders changed between the surveys. Myctophid larvae were generally dominating in the larval community over most of the station grid surveyed and particularly at its northeastern margin (Fig. 3). As shown by Figure 4, this dominance was generally at the expense of "Gonostomatidae". "Gonostomatidae" sensu lato as, for example, used by Grey (1964) includes the families Gonostomatidae, Photichthyidae and the sternoptychid subfamily Maurolicinae. Local exceptions in the dominance of myctophid larvae were furthermore caused by higher abundances of neritic fishes (Fig. 5; for details see below). 
Mauritanian Province boundaries

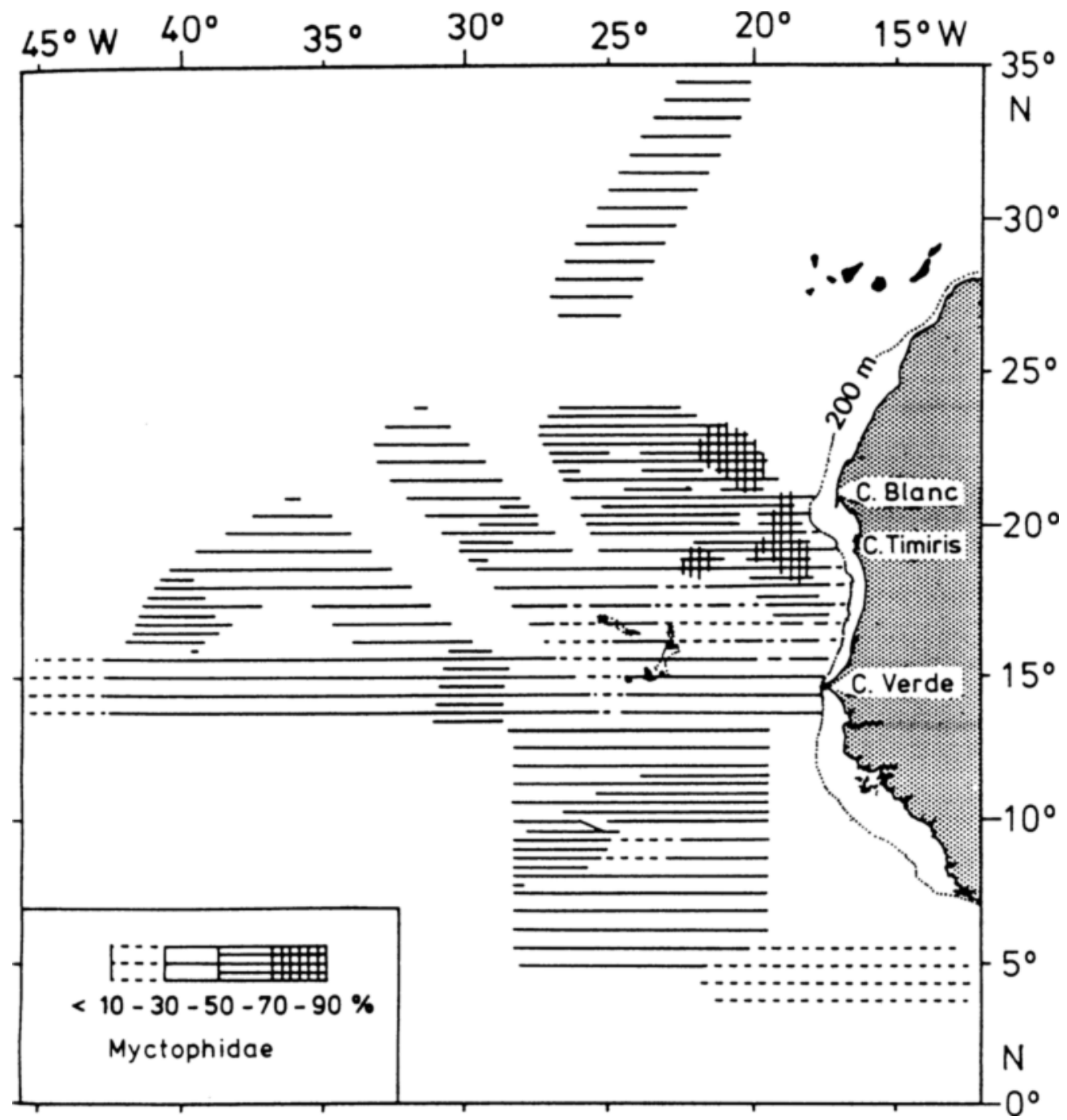

Fig. 3. Prevalence of Myctophidae as percentage of total ichthyoplankton 
H.-Ch. John \& C. Zelck

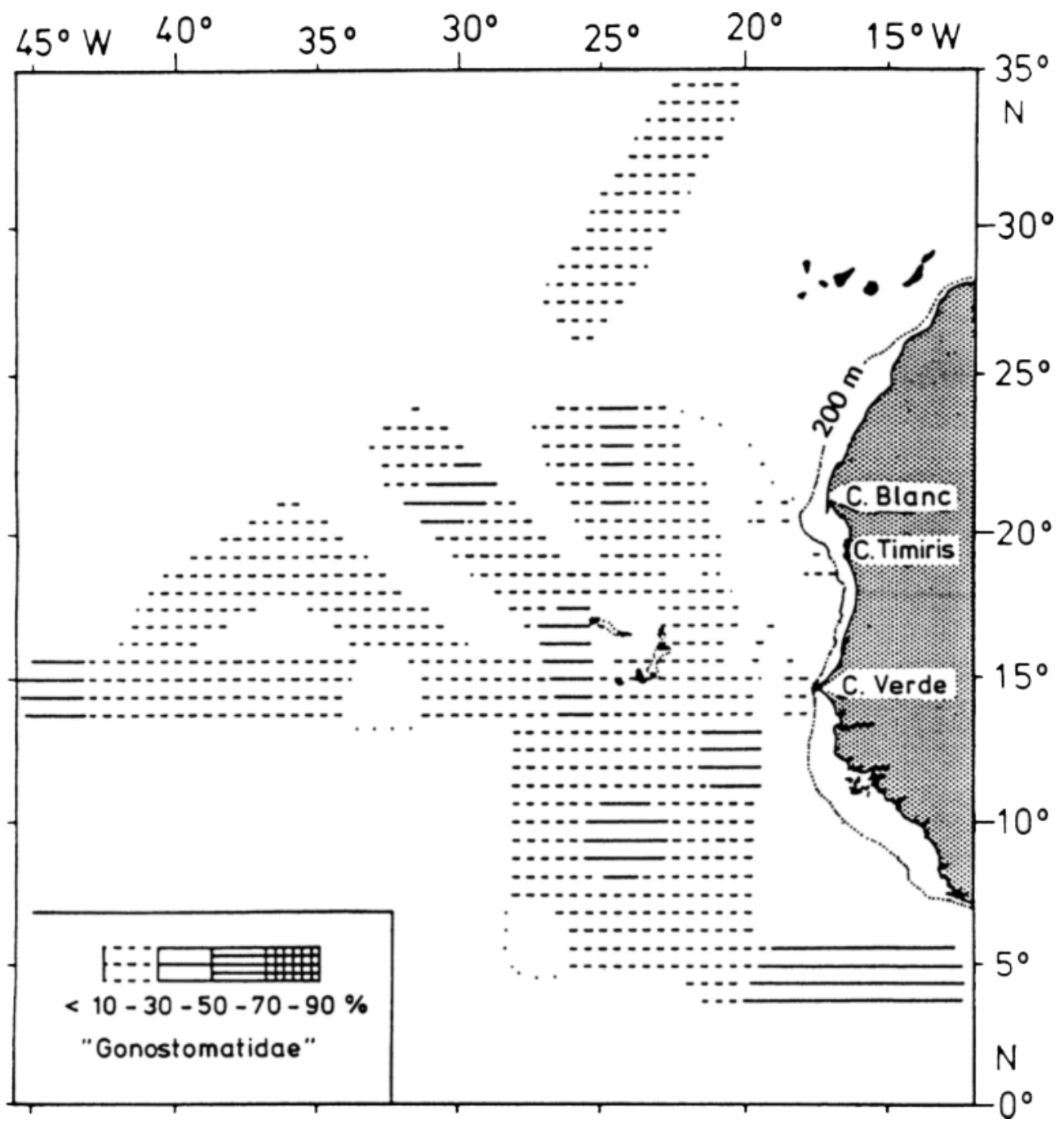

Fig. 4. Prevalence of "Gonostomatidae" (sensu lato) as percentage of total ichthyoplankton 


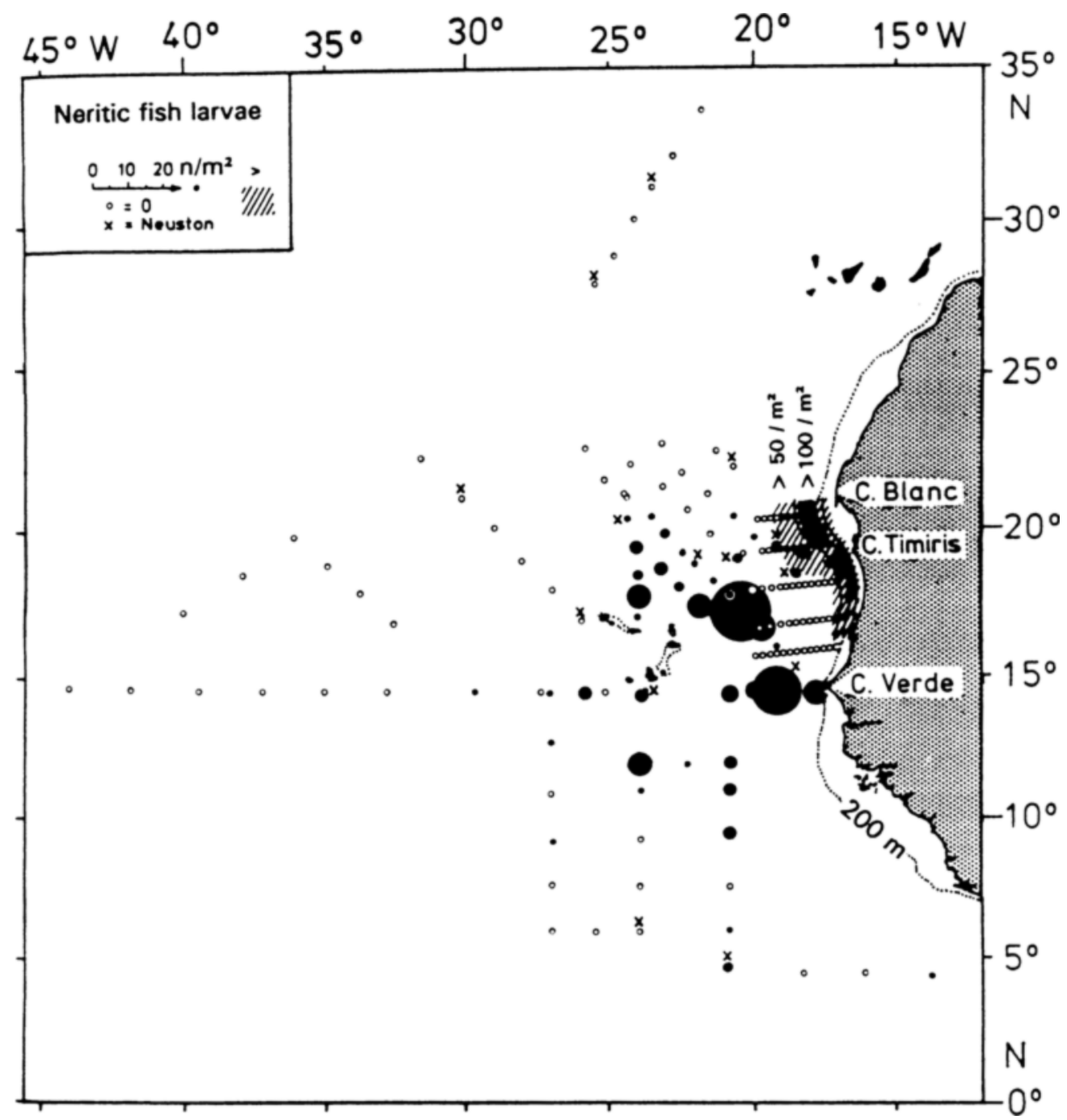

Fig. 5. The distribution and abundance of larvae of neritic and slope-dwelling fishes (but excluding pseudoceanic Myctophidae). The scale of abundance is shown in the upper inset

Within these large-scale patterns subsets of stations were revealed by a statistical analysis of dissimilarities between stations, as well as by the distribution patterns of selected species.

Since many NEU-species revealed diurnal periodicities in their availability to the sampler, a meaningful statistical analysis could be conducted only for the 28 first ranking MCN-taxa. These taxa, named in Figure 6, amounted to $64.4 \%$ of the total MCN-catch. The results of the analysis are listed in Table 1 and the mean species composition for each cluster is shown in Figure 6. The location of the clusters is shown in Figure 7 . Table 2 presents a zoogeographical classification of each cluster and its characteristical components. 


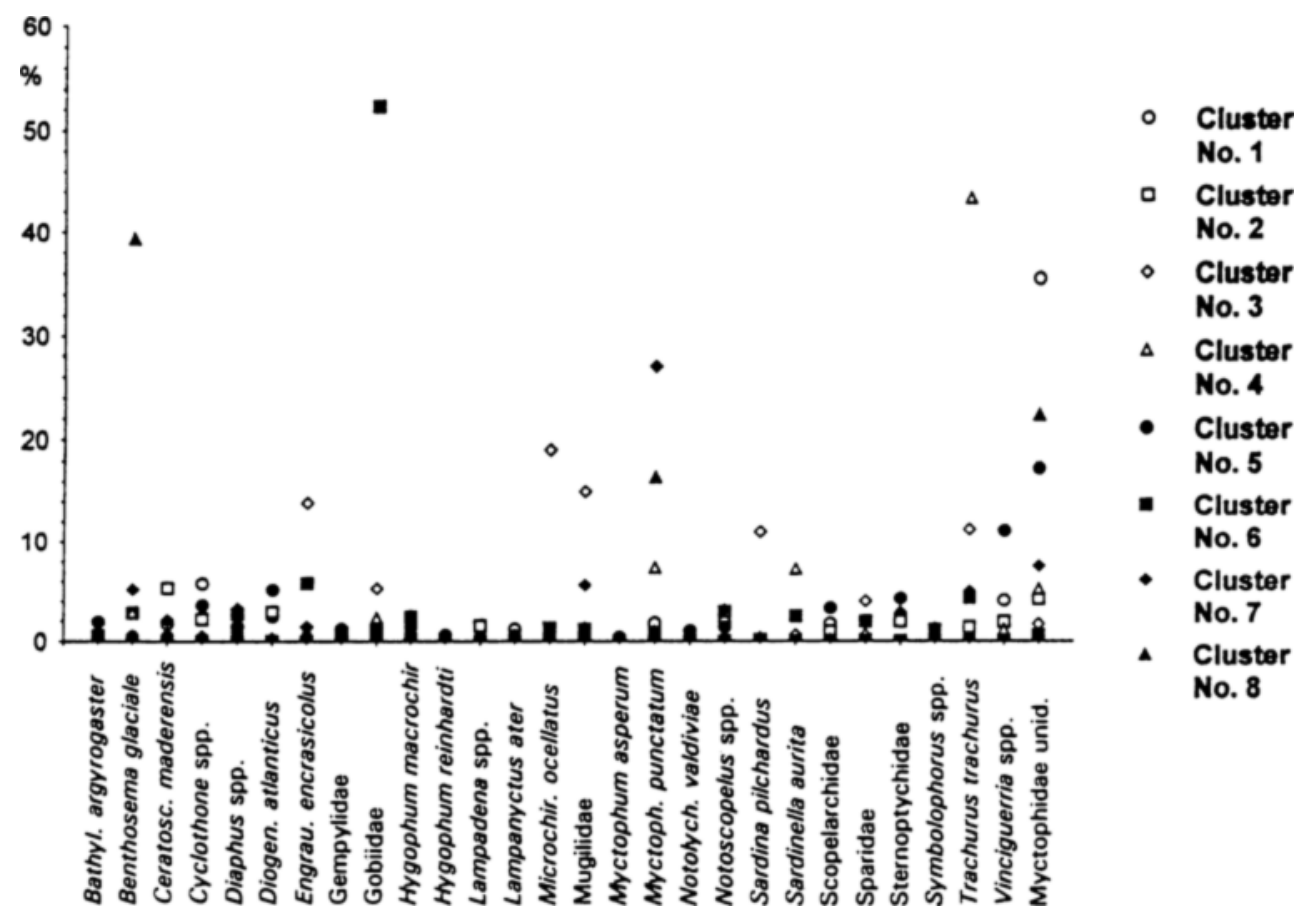

Fig. 6. Plot of mean relative abundances of the 28 first-ranking MCN-taxa (alphabetical order) in 8 individual clusters

Irrespective of the number of clusters chosen, three coastal clusters persisted together with a "cold-water myctophids" cluster along the northern Mauritanian slope. These 4 clusters remained almost consistent in their respective station composition. Another cluster in the centre of the "Mauritanian Bight" changed somewhat in its extension depending on the overall number of clusters chosen, but less so in its location. The change in extension was on account of the "Mauritanian Province boundary cluster".

However, an overall number of 7 or less clusters tended to merge the two oceanic patterns into one single large cluster only. Such an oceanic cluster would also include erroneously some few low-abundance coastal stations yielding neritic species. As such results contrast with the undisputed knowledge on the large-scale zoogeography of the tropicalsubtropical NE-Atlantic (references given in the introduction), the 8-cluster run was used.

The statistical distance between the northern and southern high-oceanic clusters (Table 1) is likely to be an underestimation. It results partly from insufficient taxonomic resolution (see below). Furthermore, some clusters seemed to scatter stations into the area of other clusters (Fig. 7). This latter result is mostly a consequence of transport processes to be discussed below. 


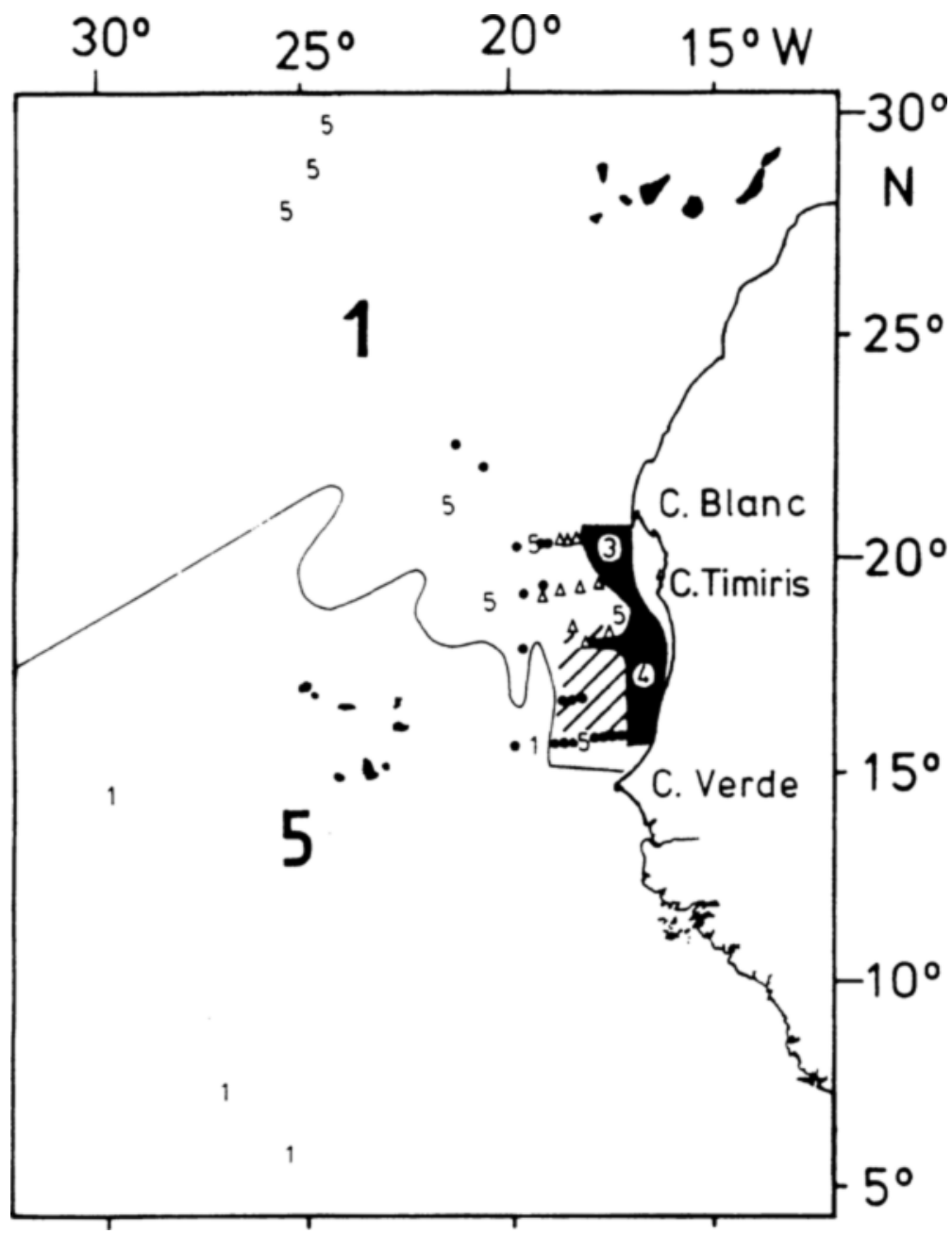

Fig. 7. The correspondence between stations and cluster numbers. The northern (cluster no. 1) and southern high oceanic (no. 5) station grids are separated by their boundary line. Respective stray stations falling into other grids are depicted by cluster numbers of smaller size. The dark area integrates the northern and southern neritic clusters 3 and 4 . The narrow midshelf cluster no. 6 running through clusters nos. 3 and 4 is not shown individually. The "cold-water myctophid" (formerly "northern Mauritanian Province") cluster no. 7 is depicted by triangles. Dots denote stations with boundary characters of the Mauritanian Province (cluster no. 2). The Mauritanian Province as newly defined is shown by diagonal hatching 
Table 1. Euclidean distances between clusters (based on the relative proportions of the 28 first ranking MCN-species)

\begin{tabular}{|crrrrrrr|}
\hline $\begin{array}{c}\text { Cluster } \\
\text { Number }\end{array}$ & No.1 & No. 2 & No. 3 & No. 4 & No. 5 & No.6 & No.7 \\
\hline No. 2 & 6.057 & & & & & & \\
No. 3 & 9.019 & 6.271 & & & & & \\
No. 4 & 10.201 & 8.284 & 8.416 & & & & \\
No.5 & 3.807 & 3.347 & 7.359 & 9.095 & & & \\
No.6 & 12.045 & 9.971 & 10.268 & 12.157 & 10.721 & & \\
No. 7 & 7.460 & 5.338 & 7.449 & 8.355 & 6.276 & 11.159 & \\
No.8 & 8.391 & 8.429 & 10.778 & 11.421 & 8.481 & 13.465 & 7.529 \\
\hline
\end{tabular}

Table 2. Zoogeographical classification and characteristics of clusters (Rank places disregard unidentified Myctophidae)

\begin{tabular}{|c|c|c|c|c|c|c|}
\hline $\begin{array}{l}\text { Cluster } \\
\text { Number }\end{array}$ & $\begin{array}{l}\text { Zoogeographical } \\
\text { classification }\end{array}$ & $\begin{array}{l}\text { N Species } \\
\text { (of } 28\}\end{array}$ & N Stas. & $\begin{array}{l}\text { Percentage } \\
\text { myctophids }\end{array}$ & $\begin{array}{l}\text { Species on } \\
\text { first rank }\end{array}$ & $\begin{array}{l}\text { Feature, typical } \\
\text { species (rank) }\end{array}$ \\
\hline 1 & $\begin{array}{l}\text { Northern-high- } \\
\text { oceanic (NACW) }\end{array}$ & 22 & 45 & 48.5 & $\begin{array}{l}\text { Cyclothone } \\
\text { braueri }\end{array}$ & $\begin{array}{l}\text { Diogenichthys } \\
\text { atlanticus (5) }\end{array}$ \\
\hline 2 & $\begin{array}{l}\text { Mauritanian } \\
\text { Province boundary }\end{array}$ & 25 & 24 & 26.5 & $\begin{array}{l}\text { Ceratoscopelus } \\
\text { maderensis }\end{array}$ & $\begin{array}{l}\text { All species } \\
\text { considered }\end{array}$ \\
\hline 3 & Northern neritic & 14 & 11 & 3.3 & $\begin{array}{l}\text { Microchirus } \\
\text { ocellatus }\end{array}$ & $\begin{array}{l}\text { Neritic species } \\
(1-5)\end{array}$ \\
\hline 4 & Southern neritic & 16 & 13 & 18.9 & $\begin{array}{l}\text { Trachurus } \\
\text { trachurus }\end{array}$ & $\begin{array}{l}\text { Sardinella } \\
\text { durita }(3)\end{array}$ \\
\hline 5 & $\begin{array}{l}\text { Southern-high- } \\
\text { oceanic (SACW) }\end{array}$ & 20 & 64 & 32.5 & $\begin{array}{l}\text { Vinciguerria } \\
\text { nimbarid }\end{array}$ & $\begin{array}{l}\text { V. nimbarid }(2) \\
\text { H. macrochir }(8)\end{array}$ \\
\hline 6 & $\begin{array}{l}\text { Midshelf } \\
\text { (not in Fig. 7) }\end{array}$ & 10 & 7 & 1.4 & Gobidae & Gobiidae (1) \\
\hline 7 & $\begin{array}{l}\text { Cold-water- } \\
\text { myctophids }\end{array}$ & 18 & 10 & 50.7 & $\begin{array}{l}\text { Myctophum } \\
\text { pinctatum }\end{array}$ & $\begin{array}{l}\text { Boreal myctophids } \\
\text { and temperate } \\
\text { neritic fishes }\end{array}$ \\
\hline 8 & $\begin{array}{l}\text { Central Mauritanian } \\
\text { Province }\end{array}$ & 6 & 3 & 80.4 & $\begin{array}{l}\text { Benthosema } \\
\text { glaciale }\end{array}$ & $\begin{array}{l}\text { Boreal }(1-3) \\
\text { and tropical } \\
\text { myctophids }(5-6)\end{array}$ \\
\hline
\end{tabular}

\section{Individual patterns}

Larvae of the family Myctophidae have on average the same abundance and frequency in the larger Mauritanian oceanic area as in the adjacent areas. However, peak abundances occurred above the northern Mauritanian slope (Fig. 8), distinguishing this area as a distinct cluster. In it the cold-water myctophids Myctophum punctatum and Benthosema glaciale were dominating. The cluster had a medium species richness including many shallow-living larvae of temperate neritic fishes.

Furthermore, the myctophid maxima off Cape Verde may be related to the CapeVerde-Tongue (CVT; see Hentschel, 1933), and the isolated maximum southwest of Cape 


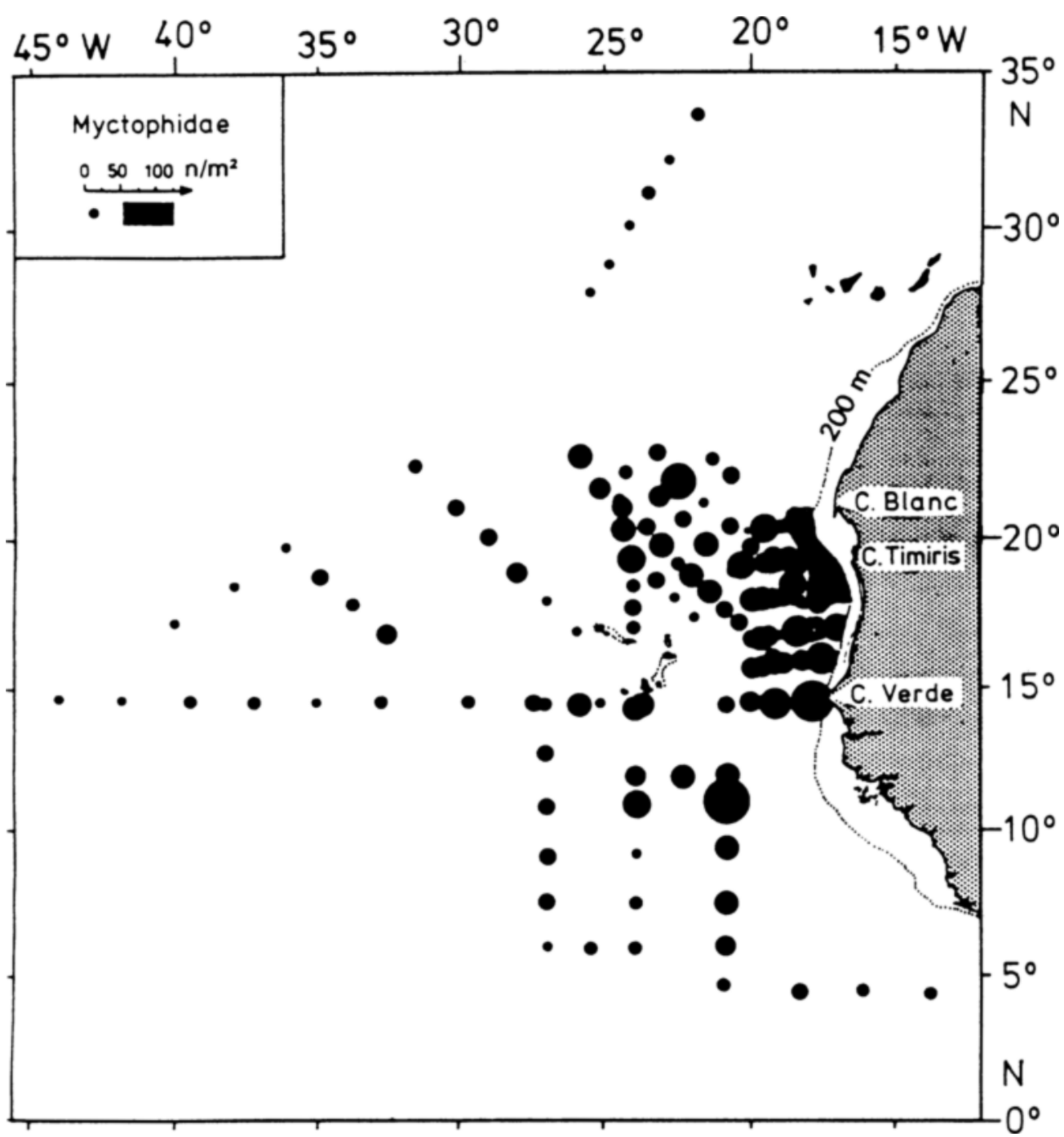

Fig. 8. Distribution and abundance of larval Myctophidae $\left(\mathrm{n} / \mathrm{m}^{2}\right.$, for scale see inset) combined for "Meteor" cruises 64, 6 and 9

Verde seems to be associated with the Guinea Dome located at about $10^{\circ} \mathrm{N}$ and $22^{\circ} \mathrm{W}$ (Siedler et al., 1992). These latter, more isolated maxima merge into the geographically large southern high-oceanic cluster. The abundance patterns of myctophid larvae are generally unrelated to the total abundance of ichthyoplankton abundance (Fig. 9), except for the mentioned maxima at the CVT, Guinea Dome and northern Mauritanian slope.

There are some areas where the proportion of larval myctophids decreases due to peak abundances of neritic taxa. This is noticeable, as expected, along the northern Mauritanian slope, and also, but this was previously unexpected, adjacent to the Cape Verde Islands. 


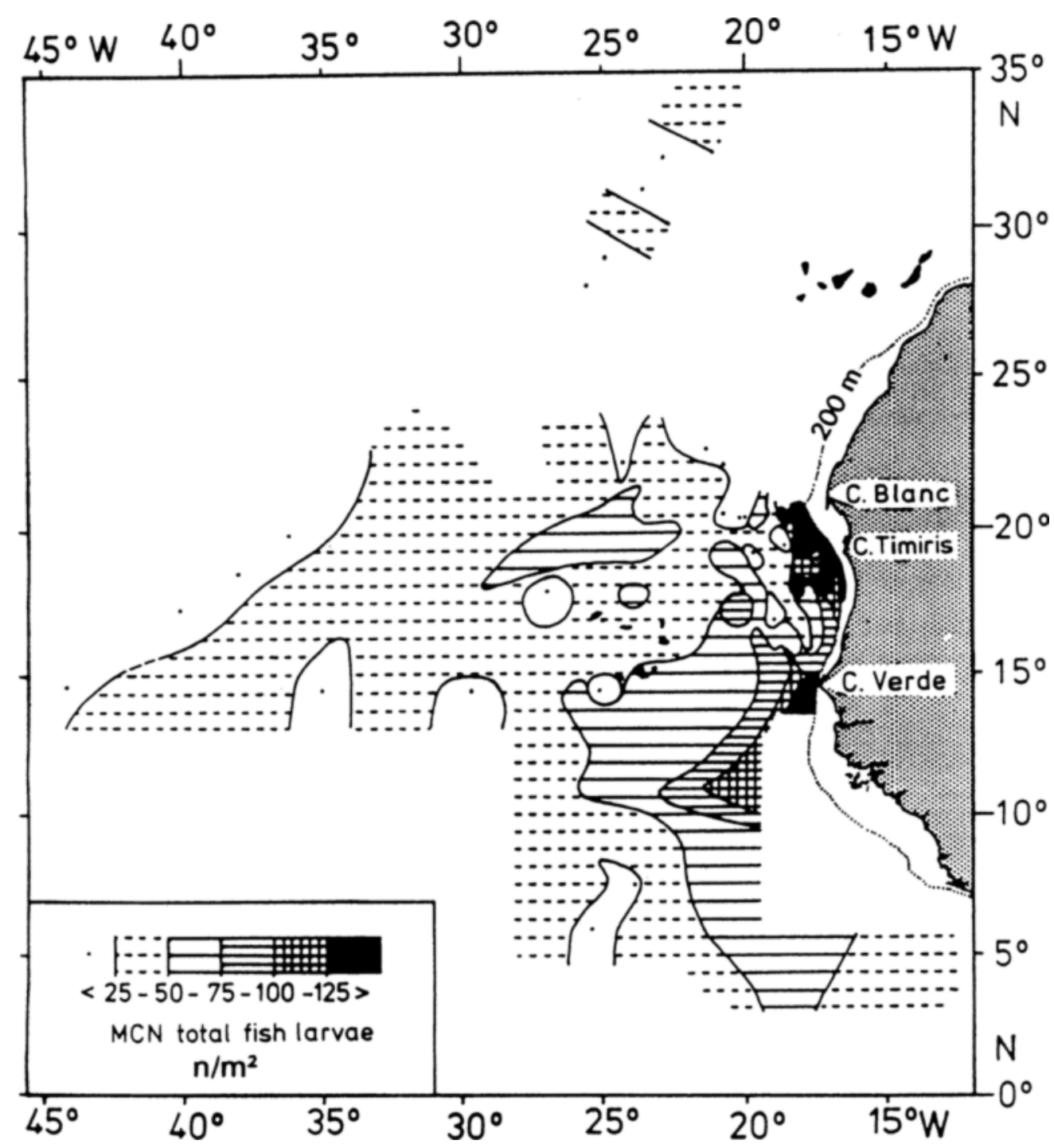

Fig. 9. The schematic abundance pattern of total ichthyoplankton (for scale see inset)

Obviously contrasting are the respective low percentages of "Gonostomatidae" over most of the station grid considered. They are particularly rare in the Mauritanian Bight (Fig. 4). Only the sternoptychid Maurolicus muelleri (a pseudoceanic species) occurred regularly above the slopes off Cape Blanc and Cape Timiris. A few stray individuals of the high-oceanic Gonostomatidae and Photichthyidae occurred along the southern Mauritanian continental slope and offshore and slightly south of Cape Timiris. "Gonostomatidae" had their highest relative abundances in the distant western and southeastern margins of the surveyed area. 
This change in relative abundance of Myctophidae and "Gonostomatidae" coincides with the Cape-Verde-Frontal-Zone (CVFZ). The CVFZ separates North- and South-Atlantic-Central-Water masses (NACW and SACW) and the northern and southern highoceanic clusters. Klein (1992) reviewed the literature on the CVFZ and the respective water mass definitions and described the actual situation during two of the surveys discussed here. The SACW-regime has generally a shallower thermocline and lower oxygen saturation. The in-situ location of the CVFZ is generally depicted by $50 \%$ and $25 \%$ NACW at $150 \mathrm{~m}$ depth (Fig. 10, data from Klein). Off Cape Timiris its location was assumed on the basis of larval data by John et al. (1991) and non synoptic hydrographical data by Hagen et al. (1985). The CVFZ rises to shallower depths towards southeast, the depicted $25 \%$ NACW location represents broadly its location in the larval depth range.

Furthermore, the above mentioned changes in relative abundance and water masses are associated with a faunal change among "Gonostomatidae". As described and discussed in relation to the converging currents at the CVFZ (Zelck, 1993), the species complex "Gonostomatidae" is dominated northwest of the front by Cyclothone (mainly temperate-subtropical Cyclothone braueri, Fig. 10). South of the CVFZ the equatorial population (see Johnson, 1986) of Vinciguerria nimbaria dominated, intruding into the province mainly in its southwestern part (Fig. 11). Some few Vinciguerria were found also along the Mauritanian slope (see also Champagnat et al., 1969). The meridional distribution of $V$. nimbaria and the dependence of its vertical distribution of the temperature structure is exemplified by a transect along $21^{\circ} \mathrm{W}$ (Fig. 12)

Larvae of central water mass myctophid species, like Lampanyctus ater (included in Fig. 10), conform to a similar pattern as C. braueri. They only rarely penetrated the CVFZ into the province. The neustonic Taaningichthys minimus did not enter the province at all.

Samples from the centre of the Mauritanian Province persisted as an individual cluster and corresponded broadly with the Mauritanian central gyre situation discussed below. The central stations were characterised by a very reduced number of species: of the 28 taxa analysed only 6 were present. Even among the first ranking and seemingly uniformly distributed group Myctophidae, distribution patterns of individual species show striking differences in respect to the boundaries of the Mauritanian Province, or within the province itself. Within the province Benthosema glaciale and Myctophum punctatum prevailed.

Peripheral to this central cluster those stations with a high species-richness, but no dominant species, represented a statistically different "boundary" cluster.

Though widely distributed elsewhere in the tropical and subtropical open Atlantic Ocean, larval Diogenichthys atlanticus were absent in the centre of the Mauritanian Province (Fig. 13). Such a minimum in the central province was even more pronounced in the family Scopelarchidae. A few D. atlanticus (and Scopelarchidae) larvae did occur off Cape Timiris and along the slope in a survey with high sampling effort (Hermes, 1987). In the boundary cluster, $D$. atlanticus had a low frequency with 6 occurrences only, but it was on rank place four in relative abundance due to higher catches at the southwestern boundary stations.

A zone of minimal abundance or absence such as described for oceanic "Gonostomatidae" and D. atlanticus (or Scopelarchidae) was found also for the species group "Oceanic Beloniformes". This group consisted of the neustonic larvae of temperate 


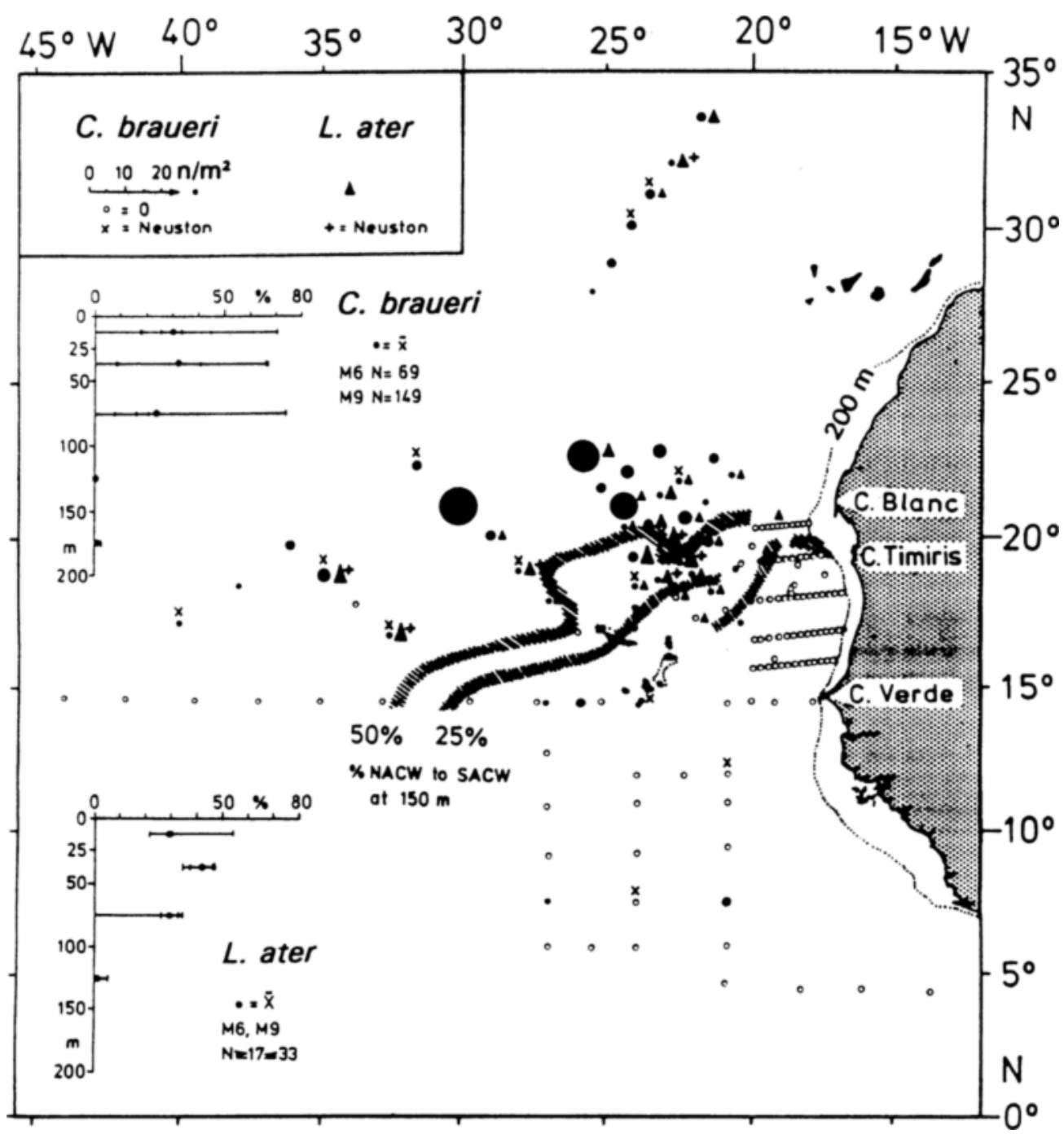

Fig. 10. Water-mass related horizontal distributions of larvae of two high-oceanic species. Cyclothone braueri (scale of abundance in the top inset) and Lampanyctus ater have a northern, central water origin. They hardly penetrate the Cape-Verde-Frontal-Zone separating North-and South-Atlantic-Central-Water (CVFZ, shaded line). The southern CVFZ-line represents its location in the larval depth range (for details see text). The average vertical distributions are shown by the insets

Scomberesox saurus, central water species Nanichthys simulans, and the 3 tropical species Oxyporhamphus micropterus, Exocoetus volitans and E. obtusirostris.

Another equatorial, SACW-type larva besides the warm stenotherm $V$. nimbaria is Hygophum macrochir (Fig. 14). Hygophum macrochir larvae have highest frequencies and abundances south of and in the CVFZ similar to $V$. nimbaria. The larvae have a deeper vertical distribution and lower temperature preferences. Therefore they can pene- 


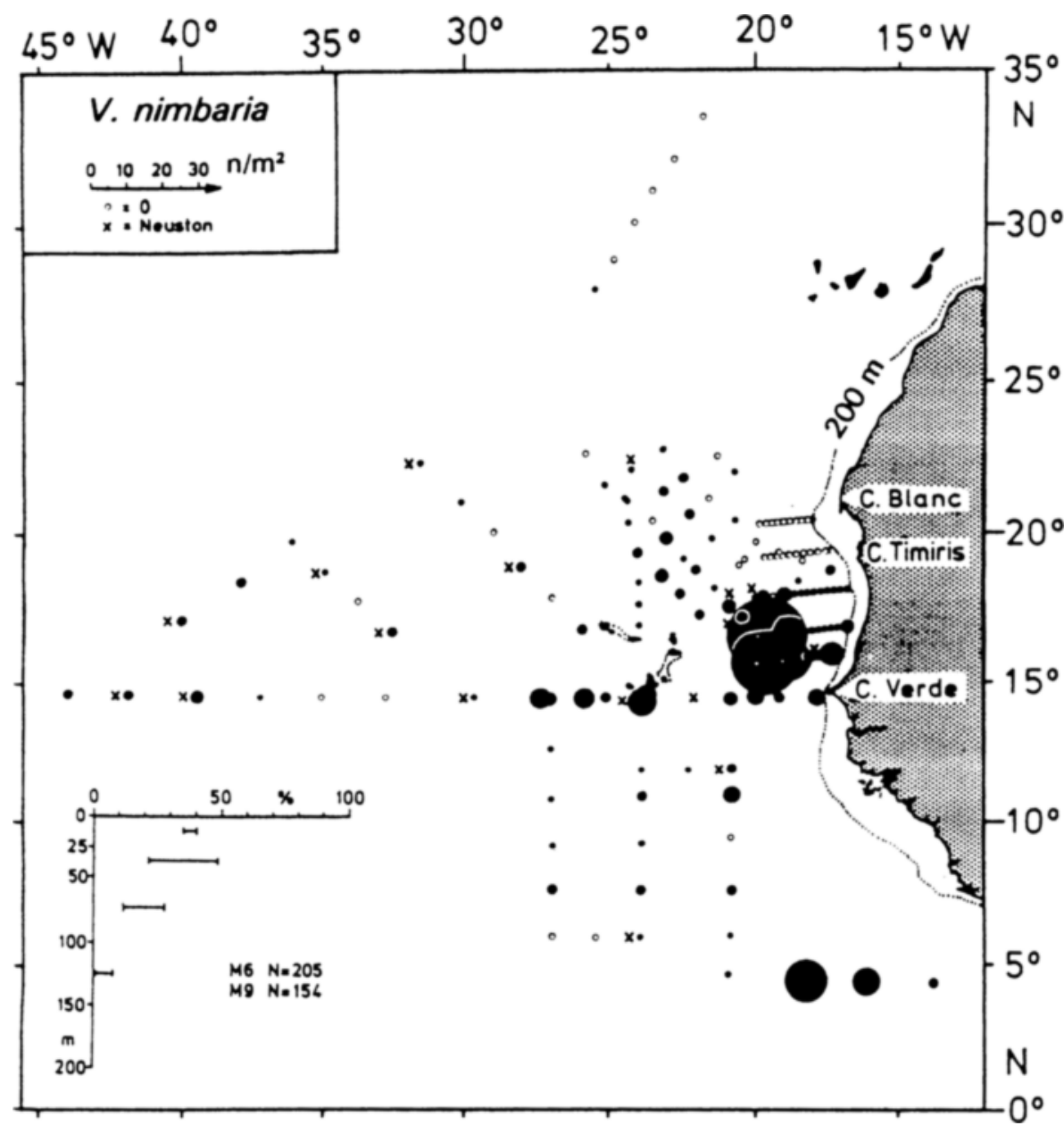

Fig. 11. Frequency, minimum abundance (top inset) and average vertical distribution (lower inset) of larvae of the equatorial species Vinciguerria nimbaria

trate further northwards along the Mauritanian slope. Hygophum macrochir seemed to have a deeper distribution northwest of the CVFZ.

Restricted along-slope, mostly narrow distributions with generally high abundances $>20$ larvae $/ \mathrm{m}^{2}$ (locally $>200 / \mathrm{m}^{2}$ ) revealed the pseudoceanic, subpolar-temperate myctophids Myctophum punctatum (John, 1986) and Benthosema glaciale (Hermes, 1987; identical Met 64 data-base each). These distributions seem to be connected with the Moroccan slope (from where we do not possess statistically comparable data) and faded out at and south of $16^{\circ} \mathrm{N}$. In the statistical analysis this northern, cold-water pattern also persisted as a distinct cluster, irrespective of the overall number of clusters tested.

Fish larvae of neritic origin occurred widely (Fig. 5). Conforming (at least superficially) with the general situation, single expatriates were found in the Canary/Cape-Verde- 


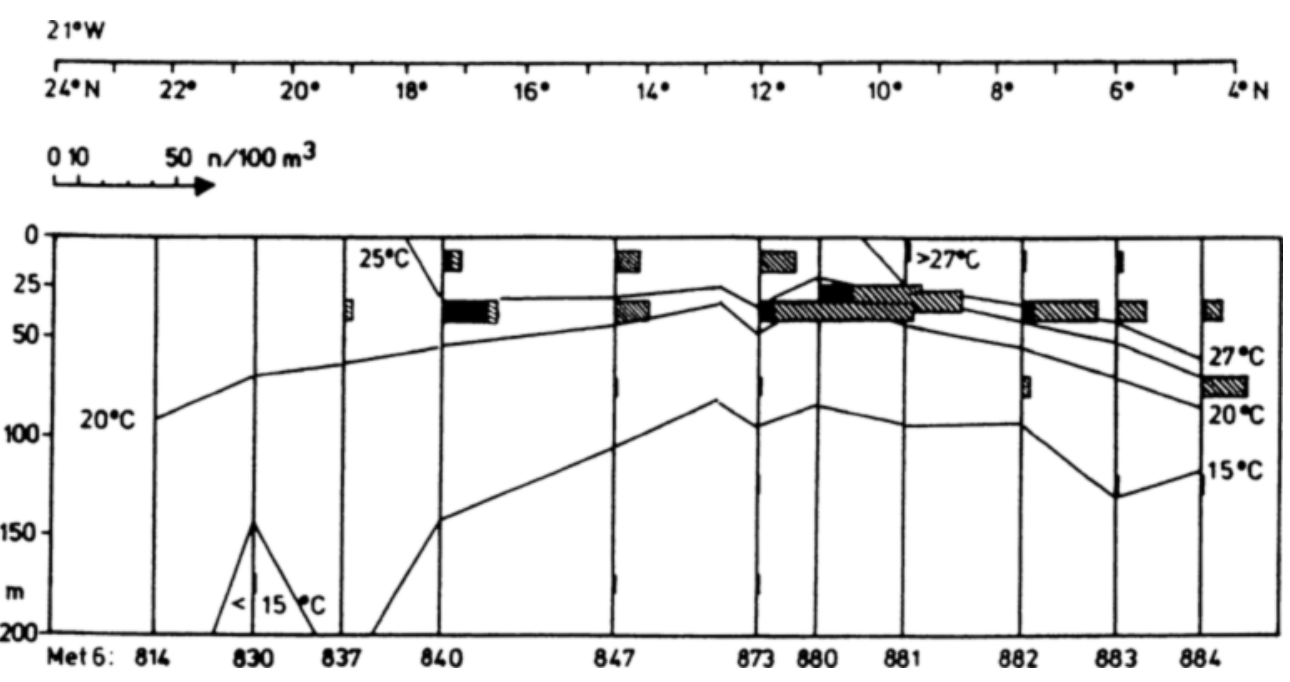

Fig. 12. Vertical distribution of larvae of the genus Vinciguerria along a meridional transect $21^{\circ} \mathrm{W}$ ("Meteor" 6 stas. 814-884), and the vertical temperature structure. Black shading of columns depicts identified postflexion $V$. nimbaria; the hatched part denotes unidentifiable small larvae belonging probably to the same species

Current system, south of the Cape Verde Islands, and in high abundances within the CVT. Along the Mauritanian coast, a northern and a southern cluster persisted together with a narrow midshelf cluster (characterised by gobiid larvae, but not of relevance for this study).

The origin and offshore dispersal of such larvae, particularly off Cape Blanc/Cape Timiris, hav been described in detail (John et al., 1991). Unexpected in respect to the previous knowledge on both zoogeography and hydrography of the area was a plume of high larval abundance in the open ocean. This plume extended from the CVT along the southwestern boundary of the Mauritanian Province, and crossed the CVFZ further in the north. This pattern on its own suggests that the CVT is related to the coastal regime south of $15^{\circ} \mathrm{N}$ and that the transport of its neritic larvae is prevailing northwestwards. This is corroborated by the similarities with the distribution patterns of $H$. macrochir, Bathylagus argyrogaster, and $V$. nimbaria. As only the less frequent and abundant $H$. macrochir and $B$. argyrogaster are part of the statistical analysis, the plume merged into the southern high-oceanic cluster. However, it is not only a very conspicuous feature in the respective specific distributions, but also in the maps of, for example, overall abundances, pooled neritic larvae or the oxygen deficit.

Adult $B$. argyrogaster is a species endemic to the tropical East Atlantic with a centre of distribution in the Gulf of Guinea and off Angola (Kobylyanskiy, 1985). It is absent off Mauritania (Maurin et al., 1977). However, larvae of the species occurred regularly at (for larvae) greater depths in noticeable frequency along the Mauritanian slope and in the southern Mauritanian Province (Fig. 15, see also Hermes \& Olivar, 1987). They were also abundant in the above mentioned plume characterised by neritic fishes plus $V$, nimbaria and $H$. macrochir. 


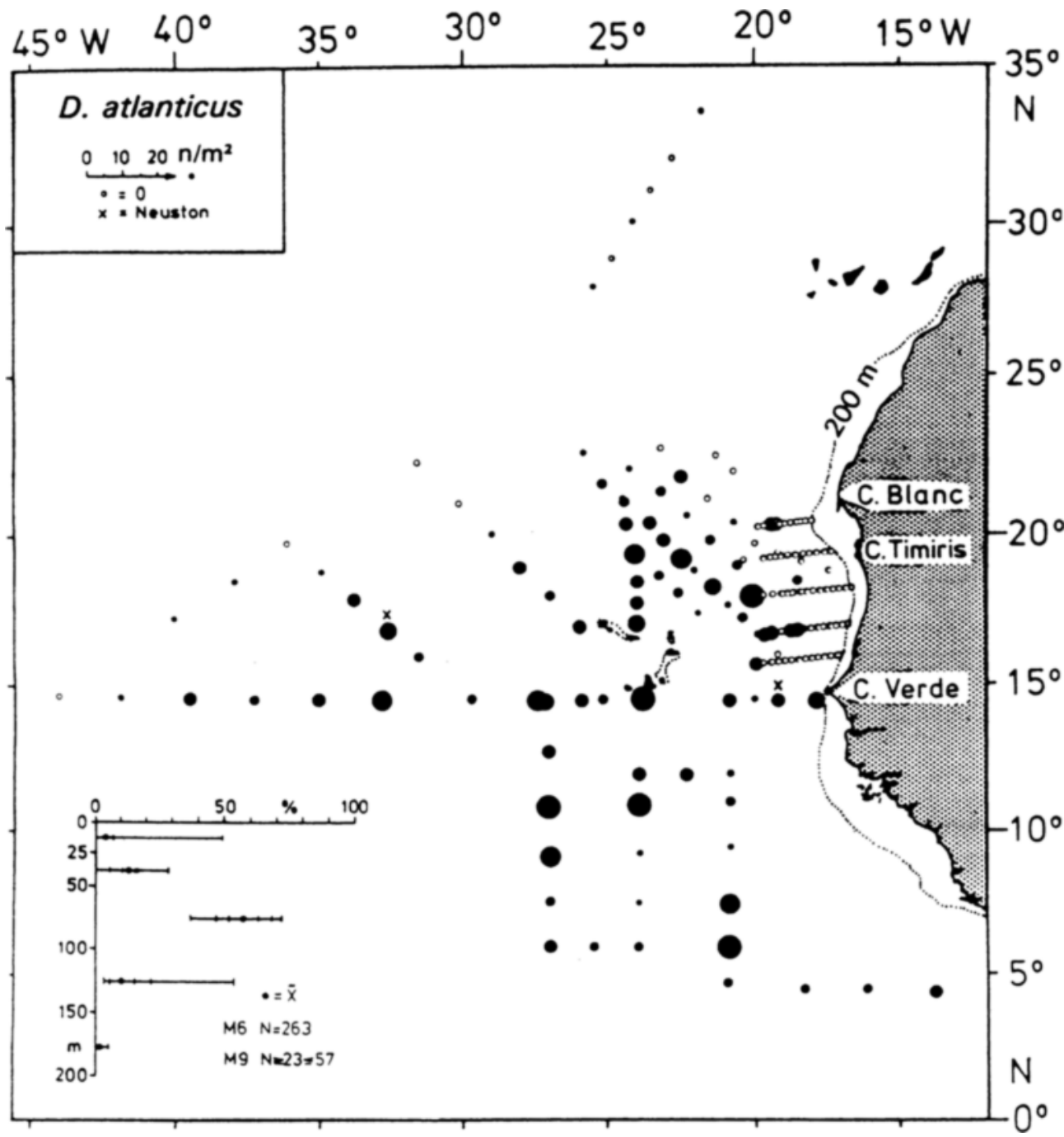

Fig. 13. Horizontal and average vertical distribution (lower inset) of larvae of the subtropical-tropical myctophid Diogenichthys atlanticus. The abundance scale is shown in the top inset. The species is almost absent off Mauritania (open station circles) 


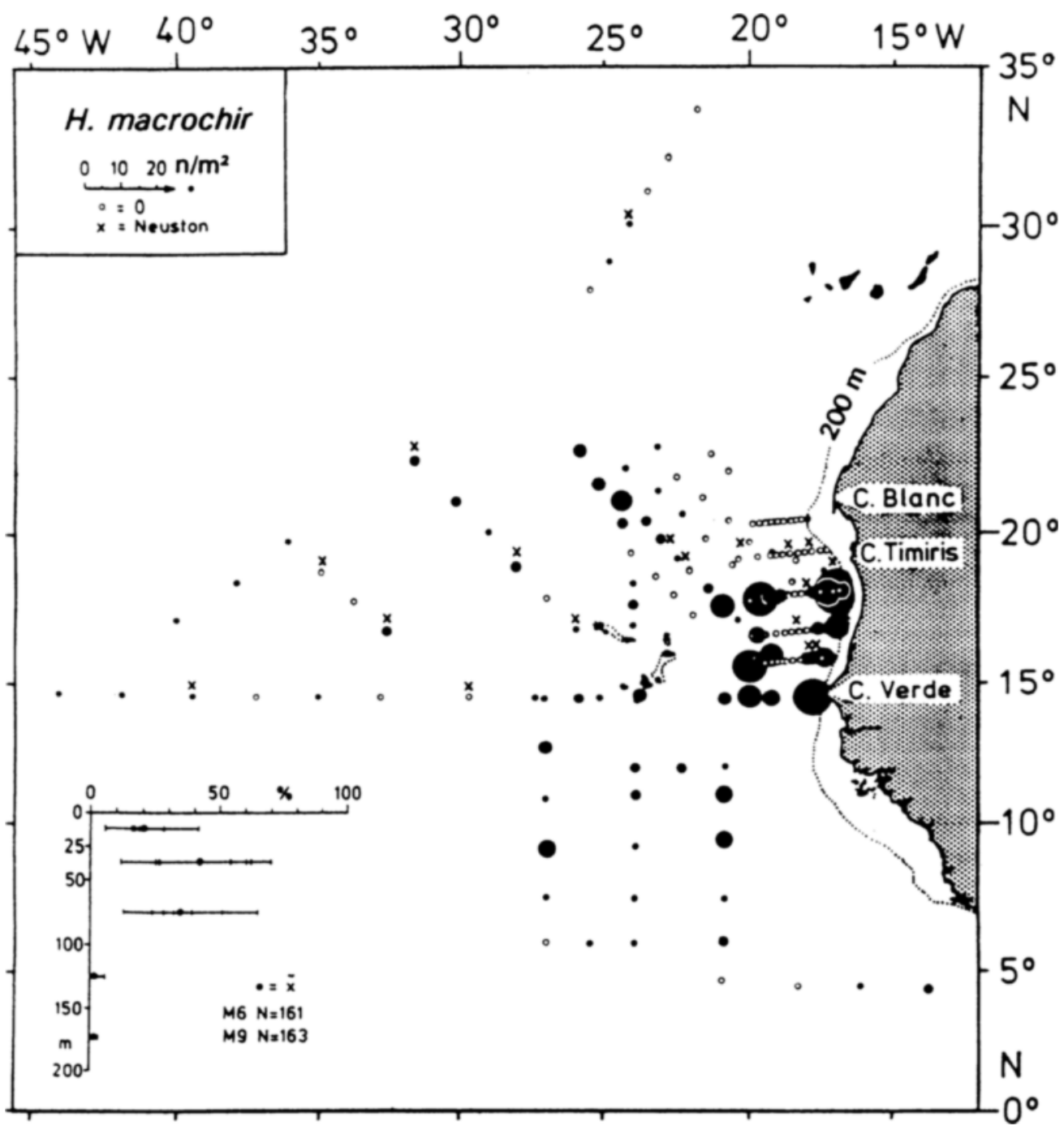

Fig. 14. Horizontal abundance (for scale see top inset) and average vertical distribution (lower inset) of larvae of the equatorial myctophid Hygophum macrochir. The species shows enhanced abundances along the eastern and western boundaries of the Mauritanian province 


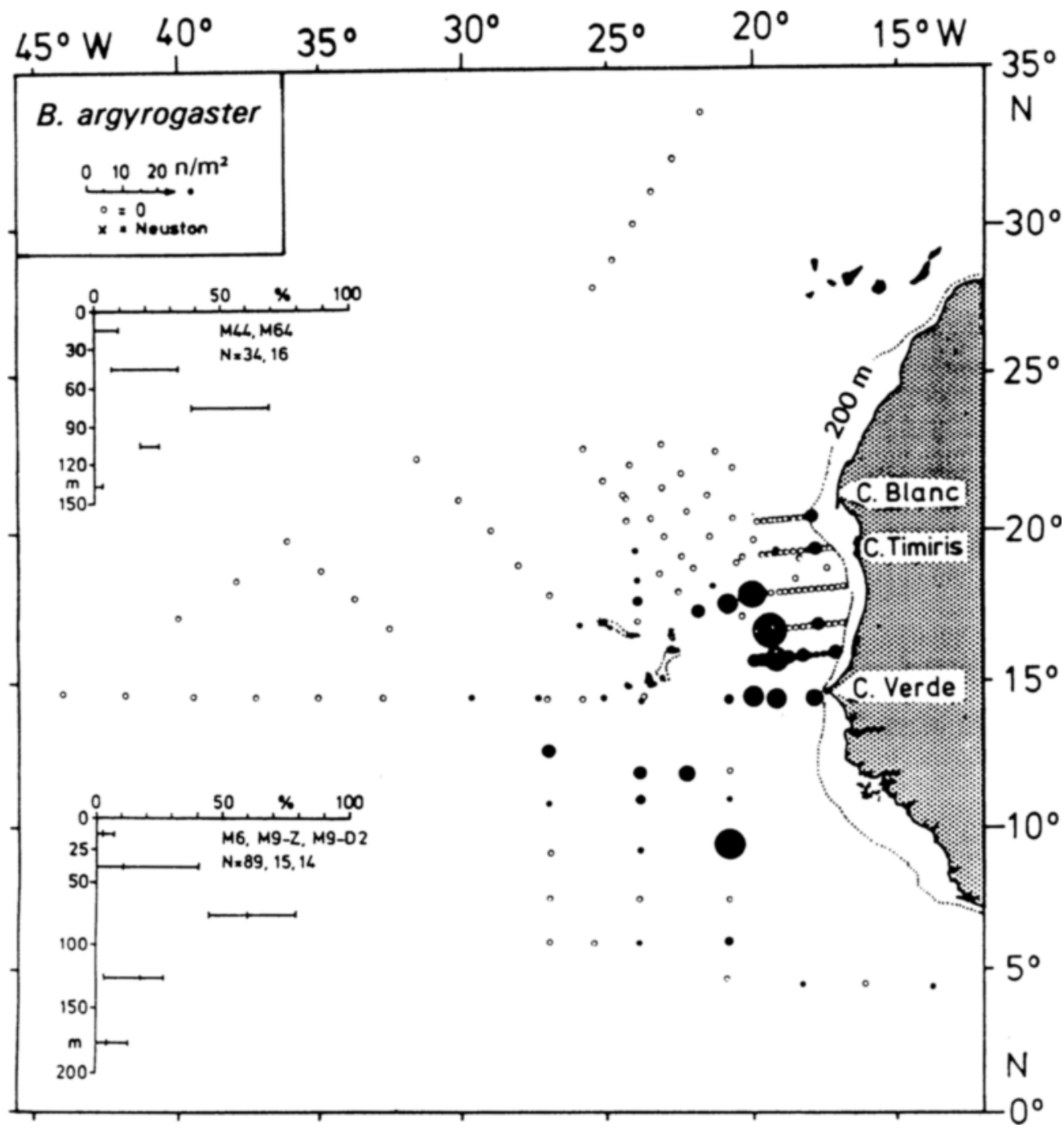

Fig. 15. Horizontal abundance (for scale see top inset) and average vertical distribution (two insets with different vertical resolutions) of larvae of the eastern-tropical endemic species Bathylagus argyrogaster 


\section{DISCUSSION AND CONCLUSIONS}

As pointed out by Loeb (1979), and corroborated by our own (unpublished) comparisons of data and literature covering 23 areas worldwide in the open ocean, the ratio between the abundances of Myctophidae and "Gonostomatidae" can be indicative of faunal regions. "Normal" for the warm open oceans are similar percentages of some 30-40\% each for myctophid larvae and those of the complex "Gonostomatidae".

As shown above, the larval assemblage of oceanic waters off Mauritania is myctophid dominated. Except for the northern Mauritanian slope area with peak abundances of northern pseudoceanic species, myctophid biomass is not in excess of the adjacent areas, and myctophid diversity decreases to a minimum in the centre of the province. By and large these findings conform with biomass and diversity data for adult myctophids (Backus et al., 1977).

The following zoogeographical features of the Mauritanian Province are noteworthy:

(a) The co-occurrences of tropical with cold-temperate North Allantic species.

(b) The intrusion of some few species of "South Atlantic endemics" in larger numbers along the eastern and western boundaries.

(c) The absence or paucity of many oceanic species, which as adults are deep-mesopelagic or bathypelagic and which occur regularly at and beyond the boundaries of the "Southern Mauritanian Province".

These peculiarities were consistent between winters of different years, and at least between the seasons autumn, winter and spring (John, 1986; for spring see Klenz, 1988; all data from different years). During summer, at least from Cape Verde to $17^{\circ} \mathrm{N}$ "Gonostomatidae" were somewhat more frequent, but not abundant (Aboussouan \& Aldebert, 1978, no specific data given, presumably Vinciguerria nimbaria).

The cold-water myctophid cluster conforms broadly with the situation of the former "Northern Mauritanian Province" as defined by Backus et al. (1977) on the basis of peak abundance of adult myctophids. However, this area lacked tropical representatives almost completely. It formed a discrete cluster in the statistical analysis due to higher percentages of particularly cold-water myctophid larvae and temperate neritic fishes. It had a comparatively low statistical distance to the adjacent oceanic realm. We do not have any own comparative data available from off Sahara and Morocco. Respective literature data (Palomera \& Rubiés, 1978) show a very similar species composition. The cold-water cluster is therefore not considered to be a discrete province.

Within the Mauritanian Province proper, the above mentioned representatives from the north and south revealed some mesoscale distribution patterns. These patterns contributed distinctly to the "boundary" cluster and caused the scattering of adjacent stations among clusters, irrespective of whether the origin of the taxon could be classified as cold-temperate, oceanic-equatorial, or tropical-neritic. However, the individual patterns differed with the origin of the taxon, and partly with its vertical distribution.

Therefore, the Mauritanian Province itself can be most easily described by the disappearance of many oceanic larval species ("Diversity Minimum") from the surface fauna as well as from the epipelagic community. The respective shape of this province is very similar to that originally defined by Backus et al. (1977), but its meridional and zonal extension is smaller. Having only a restricted station grid, Backus et al. (1977) had depicted the boundaries on the basis of the upwelling-related temperature deficit, which may 
reach as far south as $10^{\circ} \mathrm{N}$ (Schemainda et al., 1975). The reduction of the province based on our findings may be the result of below-average southward windstress and upwelling during our sampling (Servain et al., 1987; Servain \& Lukas, 1990), whilst upwelling was more intense in the sixties and early seventies (Michelchen, 1989).

Nevertheless, comparing individual station data from Nafpaktitis et al. (1977; same data base as for Backus et al., 1977) and our data for the area of the diversity minimum, very similar biological boundaries or mesoscale features are revealed (both boundarydata-sets come from autumn). The resulting northern and western boundaries of the Province (at Cape Timiris, respectively $20^{\circ} \mathrm{W}$ ) coincided with the in-situ location of the CVFZ in the larval depth range. The southern boundaries seem to agree with tropical sea-surface temperatures throughout the year (e.g. Mittelstaedt, 1991) at about Cape Verde, but need further discussion below.

Based on quantitative mapping of frequency and abundance data as well as the statistical analysis of relative species compositions, larvae of several oceanic-subtropical adults have their distribution boundaries towards the Mauritanian Province at about the in-situ position of the CVFZ.

Converging currents along the CVFZ (see John et al., 1991 for the coastal zone, Fiekas et al., 1992 for the open ocean) act as an isolating mechanism against larval dispersal across the front into the province, but rather less so as a barrier stopping larval emigration out of the province.

In the area in question the large-scale surface circulation causes a generally shallow mixed layer (e.g. Olbers et al., 1985) and, consequently, oxycline (Fig. 16). Barnett (1984) concluded that similar conditions in the eastern tropical Pacific limited species distributions. However, in evolutionary scales midwater oxygen deficits may cause speciation (White, 1987). In this respect it is noteworthy that the generally oceanic and mesopelagic species Benthosema glaciale and Myctophum punctatum off Mauritania acquire a pseudoceanic character and a shallow vertical distribution (Badcock, 1981). The Mauritanian B. glaciale are in some meristic characters closer to specimens from the Mediterranean Sea than to those from the northern NE Atlantic (Badcock, 1981).

As a rule in the eastern tropical world oceans the percentage of "Gonostomatidae" decreases (unpublished comparison of data from 23 areas worldwide). A sharp doming of oxygen-depleted water inside of the CVFZ (less than $30 \%$ saturation locally rising to $80 \mathrm{~m}$, see Zelck \& Klein, 1995) limits the distribution of mesopelagic adults with daytimedepths between 200 and $800 \mathrm{~m}$, while the above mentioned shallow-mesopelagic species occur more widely throughout the province.

However, an identical boundary is found for temperate and subtropical sauries Scomberesox saurus and Nanichthys simulans, which are neustonic throughout their life and probably not affected by the oxygen deficit. In this group as well as for neustonic larvae of mesopelagic adults, the Ekman-drift hampers larval dispersal eastwards into the province. The offshore dispersal of shallow living fish larvae with Ekman-drift has been described by John et al. (1991). The temperature deficit associated with offshore Ekmantransport may suppress spawning of neustonic adults.

As mentioned above, the occurrence of cold-water species in this area is generally explained by the coastal upwelling regime. It entrains northern species southwards by the coastal jet at least seasonally, and at the same time it creates low temperatures facilitating survival and reproduction of neritic and pseudoceanic species widely beyond 


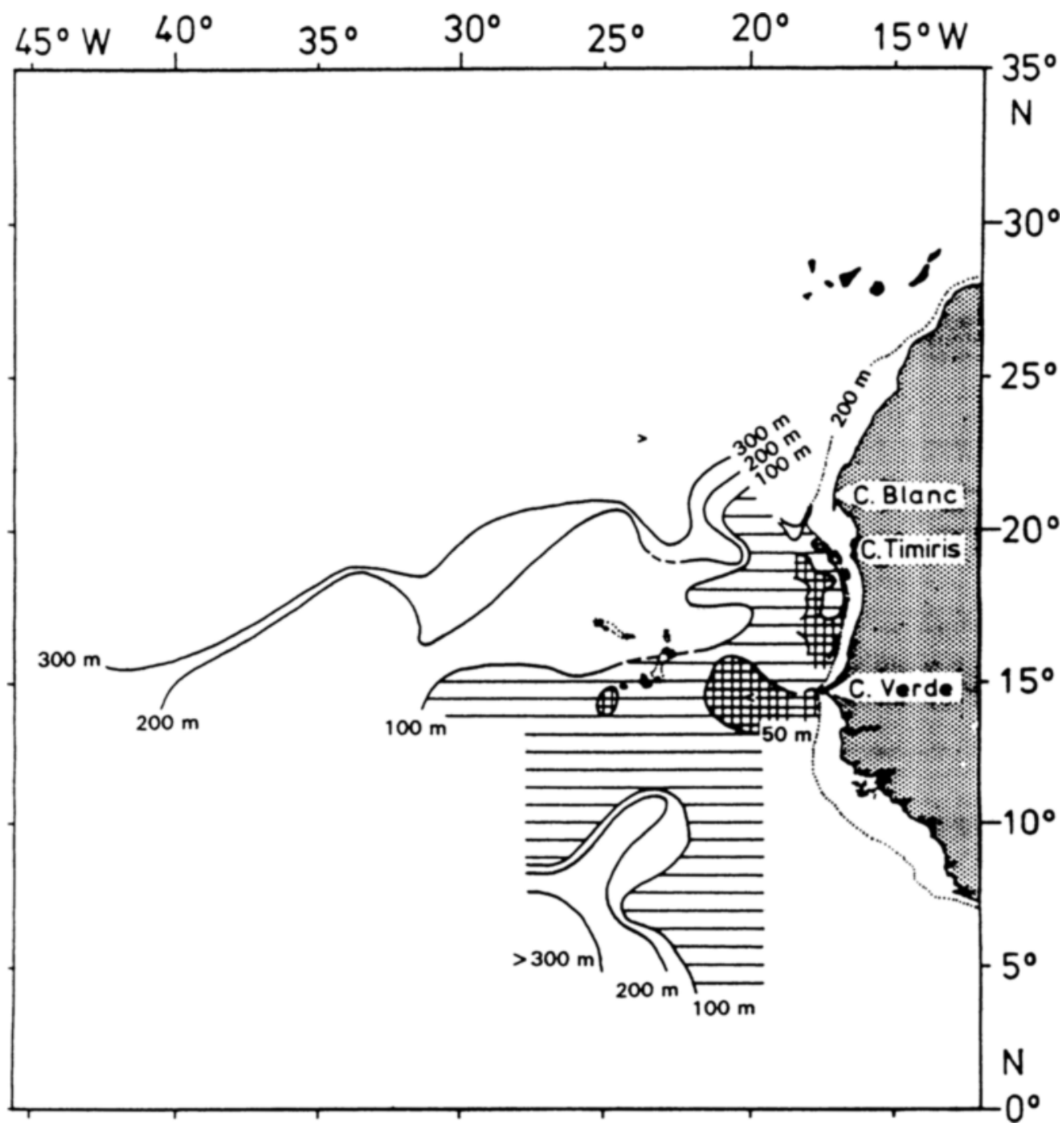

Fig. 16. The ascent of the oxygen deficient layer in the tropical NE Atlantic, exemplified by the upper isopleth of $2.5 \mathrm{ml} / \mathrm{l}$ oxygen. Cross-hatching indicates depths shallower than $50 \mathrm{~m}$. Open ocean values are in-situ data; for the area off Mauritania they were measured one month later than the plankton survey (see text)

their latitudinal range elsewhere. On the other hand, this temperature deficit probably hampers reproduction of tropical expatriates at least during the cooler months.

The along-slope poleward undercurrent below the southward surface flow can act as a recirculation or maintenance system (Badcock, 1981; Hamann et al., 1981; Parin, 1986). The above mentioned pseudoceanic myctophids seem to be well adapted to the undercurrent regime. High abundances coincided with the situation of the undercurrent off northern Mauritania and a tongue of vertically deeper oxygen saturation (non synoptic 
data, see below). A much shallower doming of oxygen-depleted water in the centre of the Mauritanian Province may limit the further seaward extension of adults, whilst the Ekman-drift facilitates dispersal of shailow living larvae from slope waters into the centre of the province. This explains the partial overlap of the cold-water myctophid and neritic clusters with the Mauritanian Province.

The coastal oxygen data were taken one month later (under upwelling conditions, Hagen et al., 1985; Lenz et al., 1985). They show for the slope realm that the undersaturation level of $<50 \%$ rises generally from about $100 \mathrm{~m}$ depth at Cape Blanc to some $30 \mathrm{~m}$ depth at about $16^{\circ} \mathrm{N}$. This may again limit the respective distributions towards the south, as in-situ surface temperatures continued southwards at comparable low values (Hermes, 1987).

As mentioned in connection with the diversity minimum, some of the species missing in the centre of the Mauritanian Province occurred infrequently along the Mauritanian slope and off Cape Timiris. A similar along-slope pattern is visible for the tropical species $B$. argyrogaster (particularly in the data by Hermes, 1987) and $H$. macrochir, intruding from the south. Both species (or the less frequent $D$. atlanticus and Scopelarchidae) have medium-deep to deep larval ranges and lower temperature preferences. Consequently, they survived entrainment by the undercurrent. In an earlier study the euphausid $N_{y c-}$ tiphanes capensis, an endemic of the southeast Atlantic, was found to be top-ranking in the Mauritanian undercurrent (Weigmann-Haass, 1976). The undercurrent descends to depths of $>200 \mathrm{~m}$ north of Cape Blanc (Mittelstaedt, 1982).

However, a branch of this undercurrent deflects off Cape Timiris seawards (Hagen et al., 1985; John et al., 1991). It forms the eastern and northern part of the cyclonic Mauritanian central gyre (Mittelstaedt, 1991) and entrains some larvae from the slope undercurrent westwards along the northern periphery of the Mauritanian gyre. The Mauritanian central gyre coincides with the diversity minimum and causes the local doming of oxygen depleted waters.

Contrasting herewith is the distribution pattern of the equatorial Vinciguerria nimbaria, having warm-stenotherm larvae distributed from near the surface to less than $60 \mathrm{~m}$ depth. They may pass Cape Verde and survive in the warmer southwestern Mauritanian Province, but larvae entrained by the along-slope poleward undercurrent can survive generally only under summer conditions (compare Champagnat et al., 1969). Vinciguerria nimbaria does not cross the CVFZ northwestwards, contrary to $H$. macrochir which had an on average deeper vertical range and lower temperature preference. The large-scale northwestward transport of $H$. macrochir caused the scatters of cluster no. 5 stations within the area of the northern high-oceanic cluster no. 1.

Hentschel (1933, and subsequent papers) related on the basis of neritic elements the CVT to the NW-African upwelling area. Since the CVT points towards southwest, the authors of this study had previously assumed an origin from the Mauritanian upwelling.

However, the shape of the plume emerging from the CVT towards northwest and the respective abundance gradients suggested dispersal towards northwest and close to the Cape Verde Islands. This is supported by the mentioned prevalence of equatorial species among the total of oceanic larvae, and among the distant neritic species southern species were also identified (Microdesmus longipinnis, Scaridae, Syacium micrurum). The above mentioned southeast Atlantic euphausid N. capensis occurred, formerly unexplainably, 
also between the Cape Verde Islands as the first ranking euphausid (Meira, 197.0). Therefore, the above mentioned plume must have had its origin in the tropics.

Hydrographic data also support the conclusion that the plume originates from the tropics. Northward transports between the Cape Verde Islands and Cape Verde, conforming with both the revealed undercurrent and offshore dispersal, were anticipated by Hagen \& Schemainda (1984, although assumed to flow offshore in a deeper layer). Mittelstaedt (1991) suggested a prevailing northeastward surface flow off Cape Verde in summer. A northward, bifurcating surface-near geostrophic flow was calculated by Olbers et al. (1985), or measured from in-situ Acoustic Doppler Current Profiler-data from Met 9 by Fiekas et al. (1992). Satellite images (Van Camp et al., 1991, in-situ data for Met 6) show for 9th December 1987 a plume of tropical sea surface temperatures (SST) conforming in form, size and location with the plume transporting tropical fish larvae. The satellite images showed that the SST-plume was larger a month before our survey and that it had vanished 2 weeks later.

Hagen (1989) described a comparable SACW-plume from summer 1972, and estimated a time scale of about a year for its separation from the undercurrent. A year seems too long in respect to the normal planktonic phase of fish larvae (except for eel), but there are no data available concerning the planktonic phase of the actually identified species. We suppose that the actual time scale was 1-3 months on the basis of the following arguments:

(a) Among the neritic larvae was the congrid eel Ariosoma balearicum, found almost everywhere in the warm open Atlantic and thus probably planktonic for several months.

(b) Along the NW-African coast the northernmost record for adult B. argyrogaster was $15^{\circ} 11^{\prime} \mathrm{N}$ (Maurin et al., 1977). Tentatively relating the larval along-slope transport of some $630 \mathrm{~km}$ with undercurrent core velocities of $25 \mathrm{~cm} / \mathrm{s}$ (Hamann et al., 1981), we obtain a minimum planktonic phase of 29 days for $B$. argyrogaster.

(c) This time span of 29 days coincides with the minimum lifetime of the SST-plume revealed by the satellite images discussed above.

The above discussed hydrographical and biological data suggest that a plume of tropical origin was consistent among at least 4 different surveys, but it may be a feature related to warmer or weak-upwelling seasons only. This seems to be corroborated by the earlier mentioned catches of $N$. capensis between the Cape Verde Islands (Meira, 1970), which yielded peak abundances from late spring to summer, whilst the species was absent in April.

\section{A TRANSPORT AND BOUNDARY MODEL OF THE MAURITANIAN PROVINCE}

As discussed above, these peculiarities of the Mauritanian Province, such as the cooccurrence of cold-water and tropical species, can be directly related to ocean currents intruding into the province. The total ichthyoplankton abundance shows striking peaks wherever there is a current input. However, there is a specifically restricted capability of larval (and sometimes adult) fish to survive there. The comparatively low temperature of the surface waters may be detrimental for larvae advected from the tropics and may inhibit spawning of tropical adults. The low oxygen saturation of the mesopelagic layer or as shallow as $80 \mathrm{~m}$ in the Mauritanian central gyre limits the distribution of adult fish as well as the survival of deep-living larvae. The low temperature and oxygen conditions 


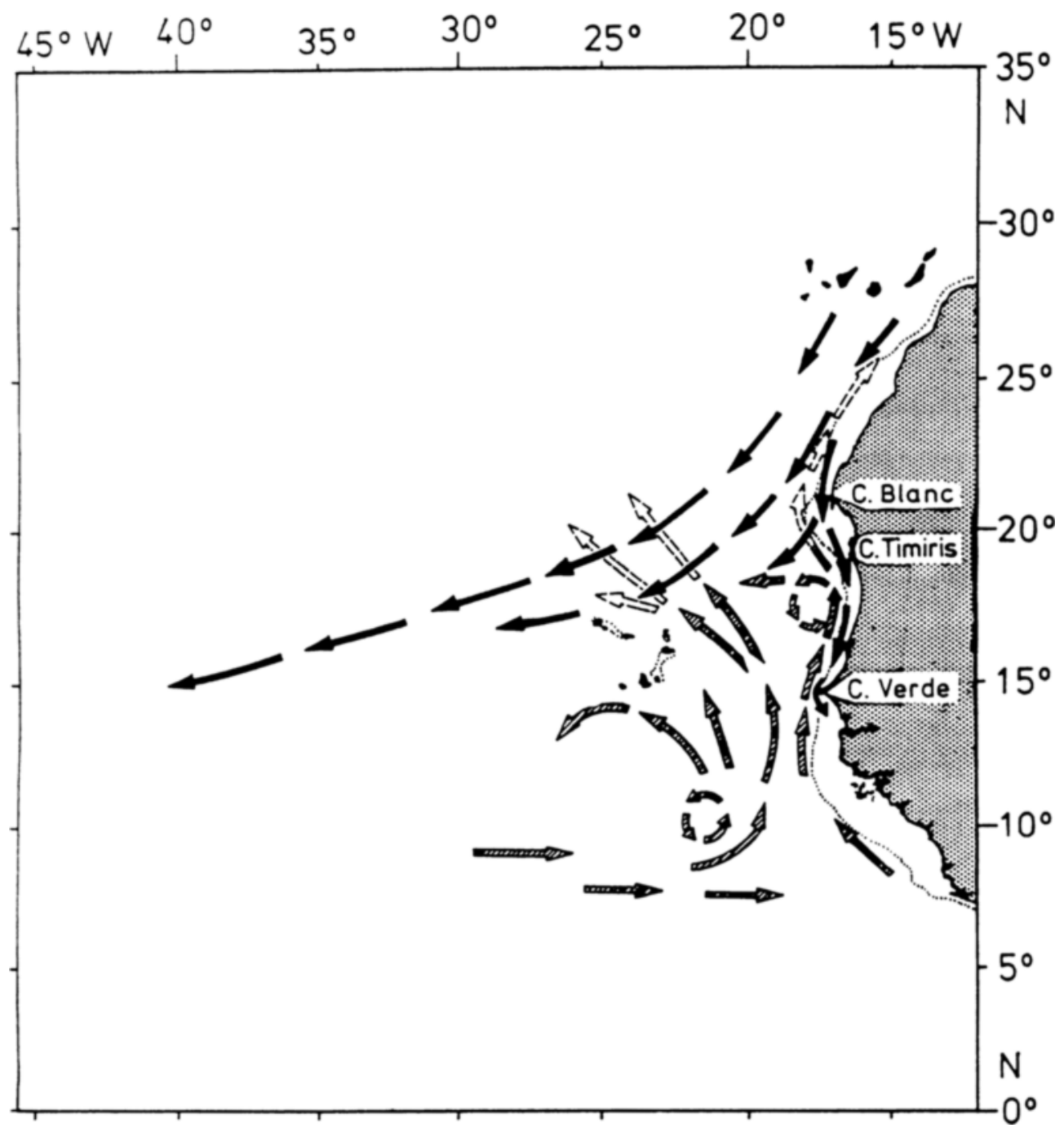

Fig. 17. An input/output model for the subsurface (30-90 m) layers of the Mauritanian province as based on the analysis of larval dispersal and hydrographic data. Black arrows indicate transport from the north by the Canary/Cape-Verde-Current and Coastal Jet. Shaded arrows indicate advection of southern, SACW-type water masses and SACW-species in the epipelagic layer, and deflections by the cyclonic Guinea Dome $\left(10^{\circ} \mathrm{N}\right)$ and by the Mauritanian Province Central Gyre. Blank, dashed arrows denote descending northward transports of SACW-origin below the general southward flow (see text). The surface Ekman-transport across the Mauritanian Province is generally towards southwest

also are partly caused (or at least geographically confined) by the circulation system. We present therefore a transport model for the subsurface-epipelagic and upper-mesopelagic layer of the Mauritanian Province (Fig. 17). It is based on the larval transport patterns 
discussed and conforms also with the above quoted recent hydrographical literature. The descending transport across the CVFZ towards northwest is biologically unknown in greater detail. Nevertheless, the respective indicator species Hygophum macrochir was traced as far as $31^{\circ} \mathrm{N} 40^{\circ} \mathrm{W}$ (unpublished data from Atlex 89), and well conforming profiles of SACW-distribution and geostrophic flow were described by Hagen $\&$ Schemainda (1987).

Acknowledgements. Sampling and evaluation of the material were funded by the "Deutsche Forschungsgemeinschaft". The colleagues from the Department of Physics of the "Institut für Meereskunde". Kiel provided hydrographical data and helped with their interpretation. Suggestions by two anonymous referees helped to improve the manuscript.

\section{LITERATURE CITED}

Aboussouan, A. \& Aldebert, Y., 1978. Note préliminaire sur l'abondance et la distribution de l'ichthyoplancton récolté au cours de la campagne de la "Thalassa" dans la zone CINECA. - ICES, Symposium on the Canary Current: Upwelling and living resources 9, 1-12.

Andres, H.-G. \& John, H.-Ch., 1984. Results of some neuston net catches in the warmer Central North Atlantic - Fish larvae and selected invertebrates. - Meeresforschung 30, 144-154.

Backus, R. H., Craddock, J. E., Haedrich, R. L. \& Robison, B. H., 1977. Atlantic mesopelagic zoogeography. Fishes of the Western North Atlantic. - Mem. Sears. Fdn mar. Res. 1 (7), 266-287.

Badcock, J., 1981. The significance of meristic variation in Benthosema glaciale (Pisces, Myctophoidei) and of the species distribution off northwest Africa. - Deep-Seat Res. 28A, 1477-1491.

Barnett, M. A., 1984. Mesopelagic fish zoogeography in the central tropical and subtropical Pacific Ocean: species composition and structure at representative locations in three ecosystems. - Mar. Biol. 82, 199-208.

Bás, C., Margalef, R. \& Rubiés, P. (Eds.), 1985. Simposio internacional sobre las areas de afloramiento mas importantes del oeste africano (Cabo Blanco y Benguela). Instituto Investigaciones Pesqueras, Barcelona, 1-2, 1-1114.

Briggs, J. C., 1974. Marine zoogeography. McGraw-Hill, New York, 475 pp.

Champagnat, C., Conand, F., Cremoux, J. L. \& Rebert, J. P., 1969. Campagne Océanographique du "Jean Charcot" (Dakar - Cap Blanc - Îles du Cap Vert) du 29-7 au 5-8-68. - ORSTOM. Centre de Recherches Océanographiques de Dakar-Thiaroye, DSP 17, 1-87.

Fiekas, V., Elken, J., Müller, T. J., Aitsam, A. \& Zenk, W., 1992. A view of the Canary Basin thermocline circulation in winter. - J. geophys. Res. 97 (C8), 12495-12510.

Grey, M., 1964. Family Gonostomatidae. Fishes of the Western North Atlantic. - Mem. Sears Fdn mar. Res. $1(4), 78-240$.

Hagen, E., 1989. Intermediäre Frontzonen vor Kap Verde $\left(15^{\circ} \mathrm{N}\right)$ ? - Beitr. Meeresk. 60, 69-71.

Hagen, E. \& Schemainda, R., 1984. Der Guineadom im ostatlantischen Stromsystem. - Beitr. Meeresk. 51, 5-27.

Hagen, E. \& Schemainda, R., 1987. On the zonal distribution of South Atlantic Central Water (SACW) along a section off Cape Blanc, Northwest Africa. - Oceanologica Acta (Nr spéc.) 6, 61-70.

Hagen, E., Schemainda, R., Michelchen, N., Zahn, W., Nehring, D., Wolf, G. \& Brenning, U., 1985. Quasistationäre Strukturen im Wasserauftrieb vor Mauretanien im März/April 1983. - Geod. geophys. Veröff. (R. 4). 42, 1-62.

Hamann, I., John, H.-Ch. \& Mittelstaedt, E., 1981. Hydrography and its effect on fish larvae in the Mauritanian upwelling area. - Deep-Sea Res. 28A, 561-575.

Hentschel, E., 1933. Allgemeine Biologie des südatlantischen Ozeans. I. Das Pelagial der obersten Wasserschicht. - Wiss. Ergebn. dt. atlant. Exped. Meteor 1925-1927 11, 1-168.

Hermes, R., 1987. Fischlarvendrift vor Mauretanien. - Diss., Univ. Hamburg, 186 pp.

Hermes, R. \& Olivar, M.P., 1987. Larval development of Bathylagus argyrogaster Norman 1930 (Teleostei, Bathylagidae). - Investigacion pesq. 51, 483-489.

Hulley, P. A., 1981. Results of the research cruises of FRV "Walther Herwig" to South America. LVIII. Family Myctophidae (Osteichthyes, Myctophiformes). - Arch. FischWiss. 31 (Beih. 1), 1-300. 
John, H.-Ch., 1976/77. Die Häufigkeit des Ichthyoplanktons an der Oberfläche des mittleren und südlichen Atlantischen Ozeans. - Meeresforschung 25, 23-36.

John, H.-Ch., 1986. On currents off north-west Africa as revealed by fish larvae distributions. Unesco tech. Pap. mar. Sci, 49, 149-155.

John, H.-Ch., Klenz, B. \& Hermes, R., 1991. Distribution and drift of horse mackerel larvae (genus Trachurus) off Mauritania January to April 1983. - C.M./ICES, H3, 1-22.

Johnson, R. K., 1986. Polytypy, boundary zones and the place of broadly distributed species in mesopelagic zoogeography. - Unesco tech. Pap. mar. Sci. 49, 156-165.

Klein, B., 1992. Die Kapverden-Frontalzone. - Ber. Inst. Meeresk. Kiel 227, 1-191.

Klenz, B., 1988. Untersuchungen zum Ichthyoplankton im Kaltwasserauftriebsgebiet vor Mauretanien. Diss., Wilhelm-Pieck-Univ., Rostock, 171 pp.

Kobylyanskiy, S. G., 1985. Material for the revision of the genus Bathylagus Günther (Bathylagidae): The group of "light" deepsea smelts. - J. Ichthyol. 25, 1-17

Lenz, J., Schneider, G., Elbrächter, M., Fritsche, P., Johannsen, H. \& Weiße, T., 1985. Hydrographic, chemical and planktological data from the North-West-African upwelling area obtained from February to April 1983 ("Ostatlantik-Biozirkel"). - Ber. Inst. Meeresk. Kiel 140, 1-105.

Loeb, V. J., 1979. Larval fishes in the zooplankton community of the North Pacific Central gyre. Mar. Biol. 53, 173-191.

Maurin, C., 1968. Écologie ichthyologique des fonds chalutables atlantiques (de la baie Ibéro-Marocaine à la Mauretanie) et de la Méditerranée occidentale. - Revue Trav. Inst. Pêch. marit. 32. $1-147$

Maurin, C., Bonnet, M. \& Quéro, J. C., 1977. Poissons des côtes nord-ouest africaines (campagnes de la "Thalassa" 1962, 1968, 1971 et 1973). Clupeiformes, Scopeliformes et Cetomiformes. Revue Trav. Inst. Pêch. marit. 41, 5-92

Meira, C., 1970. Contribuçao para o estudo dos eufausiáceos do arquipélago de Cabo Verde. - Notas Centro biol. aquát. trop. 19, 1-25.

Michelchen, N., 1989. Auswirkungen globaler und regionaler Anomalien im System Ozean - Atmosphäre auf den kustennahen Kaltwasserauftrieb im zentralen Ostatlantik. - Geod. geophys. Veröff. (R. 4), 44, 1-82

Mittelstaedt, E., 1982. Large-scale circulation along the coast of North West Africa. - Rapp. P.-v. Reun. Cons. int. Explor. Mer 180, 50-57.

Mittelstaedt, E., 1991. The ocean boundary along the northwest African coast: Circulation and oceanographic properties at the sea surface. - Prog. Oceanogr. 26, 307-355.

Müller, T.J., Siedler, G. \& Zenk, W., 1988. FS “Meteor", Reise Nr. 6. Atlantik 87/88-Fahrtabschnitt Nr. 1-3, Oktober - Dezember 1987 . Berichte der wiss. Leiter - Ber. Inst. Meeresk. Kiel 184, 1-77.

Nafpaktitis, B. G., Backus, R. H., Craddock, J.E., Haedrich, R. L., Robison, B. H. \& Karnella, C., 1977. Family Myctophidae. Fishes of the Western North Atlantic. - Mem. Sears Fdn mar. Res. $1(7)$, $13-265$.

Olbers, D. J., Wenzel, M. \& Willebrand, J., 1985. The inference of North Atlantic circulation patterns from climatological hydrographic data. - Rev. Geophys. 23, 313-356.

Palomera, I. \& Rubiés, P., 1978. Kinds and distribution of fish eggs and larvae off Northwest Africa, April - May 1973. - ICES, Symposium on the Canary Current: Upwelling and living resources 57. $1-6$.

Parin, N. V., 1986. Distribution of mesobenthopelagic fishes in slope waters and around submarine rises. - Unesco tech. Pap. mar. Sci. 49, 226-229.

Schemainda, R., Nehring, D. \& Schulz, S., 1975. Ozeanologische Untersuchungen zum Produktionspotential der nordwestafrikanischen Wasserauftriebsregionen 1970-1973. - Geod. geophys. Veröff. (R. 4) 16, 1-88.

Servain, J., Seva, M., Lukas, S. \& Rougier, G., 1987. Climatic atlas of the tropical Atlantic wind stress and sea surface temperature: 1980-1984. - Ocean-Air Interact. 1, 109-182.

Servain, J. \& Lukas, S., 1990. Climatic atlas of the tropical Atlantic wind stress and sea surface temperature: 1985-1989. IFREMER, Brest, 1-133.

Siedler, G., Peters, H., Schnack, D. \& Weikert, H., 1983. FS "Meteor" Reise Nr. 64. (Ostatlantik Biozirkel, Ostatlantik - Warmwassersphäre. Januar-Mai 1983). Berichte der wiss. Leiter. - Inst. Meeresk., Kiel, 106 pp. 
Siedler, G., Zangenberg, N., Onken, R. \& Morliere, A., 1992. Seasonal changes in the tropical Atlantic circulation: Observation and simulation of the Guinea Dome. -J. geophys. Res. 97 (C1), $703-715$.

Statistica, 1994. Statistics 11. - StatSoft, Tulsa, 3, 3001-3958.

Van Camp, L., Nykjaer, L., Mittelstaedt, E. \& Schlittenhardt, P., 1991. Upwelling and boundary circulation off Northwest Africa as depicted by infrared and visible satellite observations. - Prog. Oceanogr. 26, 357-402.

Weigmann-Haass, R., 1976. Verbreitung und Verteilung der Euphausiacea (Crustacea) im Auftriebsgebiet vor NW-Afrika. "Meteor"-Reise 19 (1970) und 26 (1972). - Meteor Forsch-Ergebn. (D) $23,62-72$.

White, B. N., 1987. Oceanic anoxic events and allopatric speciation in the deep sea. - Biol. Oceanogr. 5, 243-259.

Whittaker, R. H., 1975. Communities and ecosystems. MacMillan, New York, 385 pp.

Wooster, W.S., Bakun, A. \& McLain, D.R., 1976. The seasonal upwelling cycle along the eastern boundary of the North Atlantic. - J. mar. Res. 34, 131-141.

Zelck, C., 1993. Horizontal and vertical distribution of Cyclothone- and Vinciguerria-larvae at a watermass-front in the NE-Allantic. - C.M./ICES, L56, 1-11.

Zelck, C. \& Klein, B., 1995. Distribution of the lanternfish Ceratoscopelus maderensis (Lowe, 1839) off Northwest Africa and its relation to water mass. - Deep-Sea Res. 42, 1411-1422.

Zenk, W., Müller, T. J. \& Wefer, G., 1989. BARLAVENTO-Expedition, Reise Nr. 9, 29. Dezember 1988-17. März 1989. - Meteor-Ber. 89-2, 1-238. 